\title{
On a new species of Spirobranchus Blainville, 1818 (Annelida: Serpulidae) and considerations on the genus along the Brazilian coast
}

\author{
Ivison Cordeiro Brandão ${ }^{1,2}$ \& Ana Claudia dos Santos Brasil ${ }^{1,3}$ \\ ${ }^{1}$ Universidade Federal Rural do Rio de Janeiro (UFRRJ), Instituto de Ciências Biológicas e da Saúde (ICBS), \\ Departamento de Biologia Animal, Laboratório de Polychaeta. Seropédica, RJ, Brasil. \\ 2 ORCID: http://orcid.org/0000-0002-0508-1351. E-mail: ivisoncblima@gmail.com (corresponding author) \\ 3 ORCID: http://orcid.org/0000-0002-0611-9948. E-mail: acbrasil@gmail.com
}

\begin{abstract}
Spirobranchus are abundant and diverse serpulids in tropical regions, with three species reported in Brazil, which occurrence is questionable, due to their distant type localities. In the present work, we describe a new species of Spirobranchus from the Brazilian coast and report the other species of the genus occurring off Brazilian shoreline, based on specimens from different locations. Specimens were collected in the states of Alagoas, Rio de Janeiro, and Santa Catarina, sorted and analyzed under a stereoscopic microscope. Then, the animals were anesthetized and subsequently fixed and prepared for the scanning electron microscopy. Specimens from the Caribbean and other Brazilian states were loaned from Museu Nacional of Universidade Federal do Rio de Janeiro, Universidade Estadual do Rio de Janeiro and Universidade Federal de Alagoas. Morphological analyzes differentiated the three species and provided details of the morphology that can be used in the future taxonomy of the family. The species $S$. giganteus and $S$. tetraceros are more similar to each other, but can be readily separated based on the spiral radiolar crown in the former; S. minutus differs from the other species for the tube, operculum, and type of uncini. Spirobranchus lirianeae sp. nov. nests within S. kraussii-complex, with a concave operculum, absence of collar chaetae and paired compound eyes on the radioles, differing by being a solitary rather than a gregarious species, by the funnel-shaped operculum, fringed tonguelets and tube with single keel, distally pointed.
\end{abstract}

Key-Words. Southwestern Atlantic Ocean; Biodiversity; Marine species; Polychaeta; Spirobranchus kraussii-complex.

\section{INTRODUCTION}

Spirobranchus Blainville, 1818 is a genus of Serpulidae, characterized by the calcareous endplate of the operculum, often with terminal thorns, lateral wing-like projections in the distal region of the triangular peduncle, and special collar chaetae, similar to bayonets but with shaft distally ornamented with numerous tiny spines and tapered serrated blade, called "Spirobranchus-chaetae" (Pillai, 2009; ten Hove \& Kupriyanova, 2009). Some species are distinguished by having spiraled radiolar crown lobes, with the radioles exhibiting length gradation-the upper ones much shorter than lower ones-making the radiolar lobe resemble a Christmas tree, endowing these animals with their common name of "Christmas-tree-worms". Spirobranchus species can be differentiated based on characters of the operculum (such as general shape, presence, number and shape of thorns, and the pattern formed by these structures, when projected from the opercular endplate), ornamentation of the tube (which may consist on longitu- dinal keels, transverse ridges and lined alveoli), in addition to other relevant characteristics, such as the photoreceptor structures in the radiolar crown, which vary from being absent to one of four types (individual radiolar ocellar clusters, simple radiolar ocelli, paired radiolar ocellar clusters, and simple opercular ocelli) (Bok et al., 2017).

The genus comprises 34 valid species, of which five were synonymized from Pomatoceros Philippi, 1844 and one from the monotypic Pomatoleios Pixell, 1913, upon understanding that the diagnostic characteristics of these six latter could be attributed to intraspecific variations of Spirobranchus (Pillai, 2009). Spirobranchus kraussii (Baird, 1865) was originally described as Placostegus cariniferus var. kraussii Baird, 1865 and later synonymized with Pomatoleios crosslandi Pixell, 1913 by Day (1955), as Pomatoleios kraussii, and reported from several locations (both as P. crosslandi and as P. kraussii) in the Indian and Pacific Oceans, and also in the Mediterranean Sea (see Simon et al., 2019 and Pazoki et al., 2020 for reviews). Nowadays, it is considered as an invasive species in several countries 
(Çinar, 2013). In a phylogeographic study of specimens from the type locality (Cape of Good Hope, South Africa), Simon et al. (2019) questioned the validity of occurrences beyond the South African coast, preferring to designate $S$. kraussii only for specimens from that region. Thus, Simon et al. (2019) postulated that S. kraussii is a complex of species, warranting further investigation on the identity of specimens collected beyond South Africa. Pazoki et al. (2020) included S. cariniferus in that complex and, moreover, described a new species within it, Spirobranchus sinuspersicus Pazoki et al., 2020 from the Persian Gulf and Gulf of Oman. Pazoki et al. (2020) emphasized that S. sinuspersicus is more likely to be invasive than S. kraussii. Currently, the Spirobranchus kraussii complex consists of S. kraussii (Southern Africa), S. sinuspersicus (Persian Gulf and Gulf of Oman), S. cariniferus (Gray, 1843) (New Zealand), Spirobranchus sp.1 (Japan), Spirobranchus sp.2 (Hawaii), Spirobranchus sp.3 (Australia), and a group of Spirobranchus cf. kraussii registered in the Mediterranean, Suez Bay, Pakistan, India, Sri Lanka, Philippines, Singapore and the Pacific side of Panama.

To date, three species of Spirobranchus have been recorded from Brazil (Amaral et al., 2013). Zibrowius (1970) conducted the first study on the genus from the Brazilian coast, identifying S. giganteus (Pallas, 1766) from the infralittoral off Fernando de Noronha (northeastern Brazil) and S. minutus from São Paulo (southeastern Brazil). Various authors subsequently reported these same species from similar regions (Rullier \& Amoureux, 1979; Morgado, 1980; Souza, 1989; Rocha, 1993, 1995; Santa-Isabel et al., 2000; Correia \& Sovierzoski, 2009). More recently, S. giganteus has also been recorded in the southeastern region of Brazil (Skinner et al., 2012) and
S. minutus (Rioja, 1941) has been registered in the northeastern region (Ananias, 2017), demonstrating that the distributions of both species could be underestimated. Although initially misidentified as S. giganteus (Skinner et al., 2012), Spirobranchus tetraceros (Schmarda, 1861) became the third species of the genus recorded in Brazil based on specimens from different parts of the State of Rio de Janeiro (Perry et al., 2017; Rodrigues et al., 2020). In the present study, using a morphological approach, we describe a new species of Spirobranchus from the southeastern coast of Brazil, representing the first record of members of the S. kraussii complex from the western Atlantic. Furthermore, we compare the other species of the genus occurring in Brazil and discuss their occurrences and distributions.

\section{MATERIAL AND METHODS}

Specimens were collected in the intertidal region of Praia do Machado and Cataguases Island, at Ilha Grande Bay $\left(22^{\circ} 50^{\prime}-23^{\circ} 20^{\prime} \mathrm{S}, 44^{\circ} 00^{\prime}-44^{\circ} 45^{\prime} \mathrm{W}\right)$, Rio de Janeiro State (Fig. 1). The organisms were removed from the substrate and transported to the laboratory still alive, anesthetized with menthol and photographed under a stereoscopic microscope, then fixed in 4\% formalin and preserved in $70 \%$ ethyl alcohol (EtOH). Some individuals were stained with methylene blue, for observation of thoracic and abdominal glandular patterns. Thoracic and abdominal parapodial lobes were dissected and mounted on permanent slides with Grey \& Wess solution (Humason, 1979), for observation of chaetae under an optical microscope. Two individuals were selected for

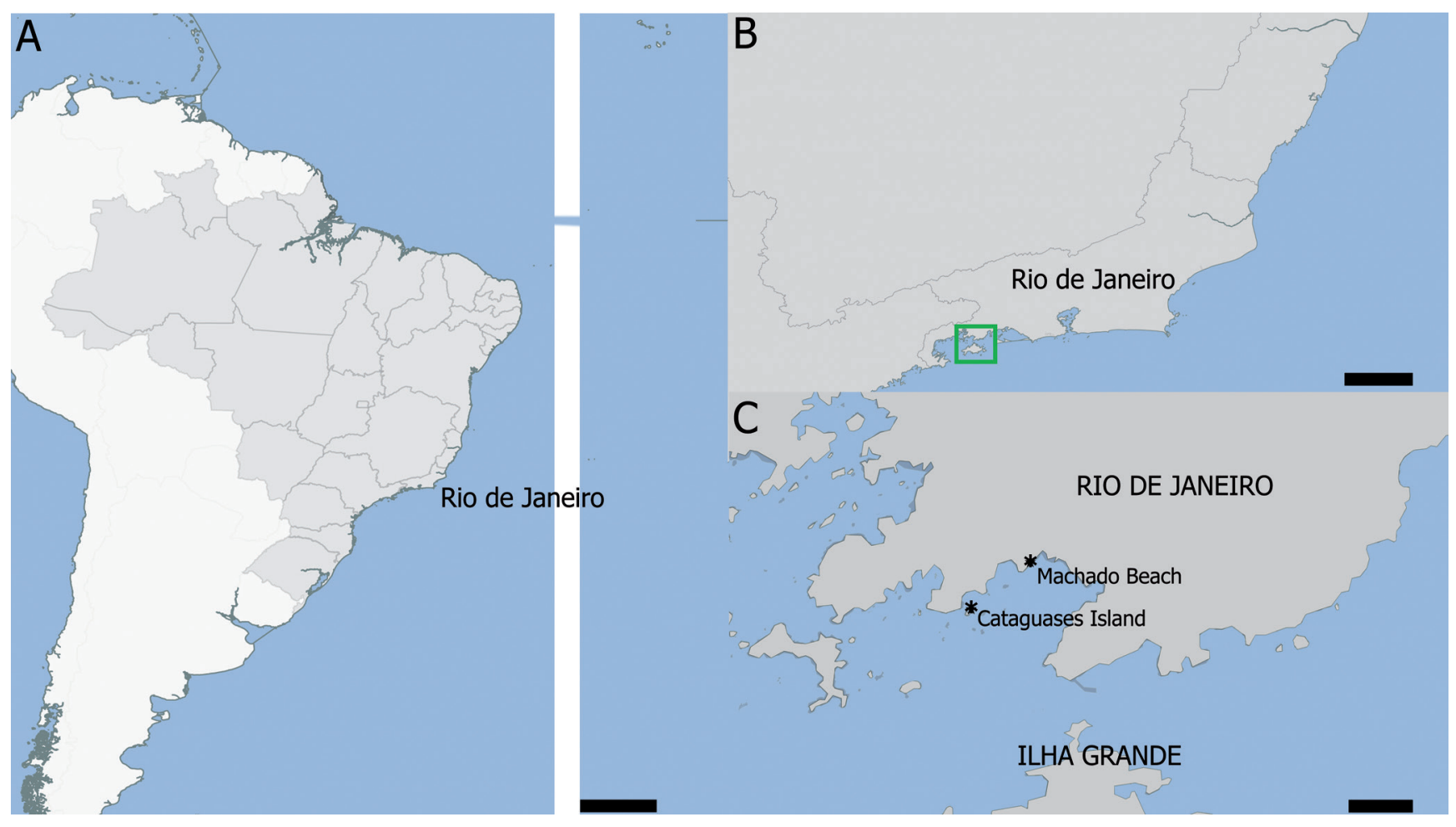

Figure 1. Type-locality of Spirobranchus lirianeae sp. nov. (A) Rio de Janeiro state location at Brazilian coast, (B) detail of Rio de Janeiro state and sample area (green square) (C) sampled locations (stars) at Ilha Grande bay. Scale bars $=250 \mathrm{~km}(\mathrm{~A}), 75 \mathrm{~km}(\mathrm{~B}), 2,5 \mathrm{~km}(\mathrm{C})$. 
the scanning electron microscopy (SEM), dehydrated in a series of ethyl alcohol at 70\%, 80\%, 90\%, and finally absolute ethyl alcohol; subsequently, they were submitted to chemical critical-point through a gradient of hexa-methyl-di-silazan (HMDS), until total evaporation of HMDS at room temperature (Miranda \& Brazil, 2014). The dehydrated individuals were mounted on aluminum stubs and coated with gold-palladium sputter, then observed under a scanning electron microscope (SEM), at Fundação Oswaldo Cruz.

Individuals of other Spirobranchus species reported in Brazil were also analyzed from zoological collections and field works carried out in different parts of the country: S. giganteus was collected in northeastern Brazil, in the State of Alagoas, as well as from the scientific collection of the Museu Nacional of Universidade Federal do Rio de Janeiro (National Museum of Federal University of Rio de Janeiro), consisting on specimens from the same region, from Abrolhos, State of Bahia, in addition to specimens from Espirito Santo, southeastern Brazil, and from the Caribbean side of Panama, near the type-locality of the species. Members of S. minutus were obtained in collections in the states of Rio de Janeiro and Santa Catarina; specimens of $S$. tetraceros were also obtained from collections in Ilha Grande Bay and Sepetiba Bay, including association with the invasive corals Tubastraea spp. Spirobranchus cf. kraussii was found forming aggregates in the intertidal region of Punta Morales (Costa Rica, Pacific Ocean) and the morphology of these animals was analyzed, for comparison with the Brazilian material and specimens of S. kraussii described by Simon et al. (2019).

\section{RESULTS}

\section{Order Sabellida \\ Family Serpulidae Rafinesque, 1815 \\ Genus Spirobranchus Blainville, 1818}

Type-species: Spirobranchus giganteus (Pallas, 1766).

Diagnosis (expanded from ten Hove \& Kupriyanova, 2009): Tube circular to triangular in cross section, one to five longitudinal keels present, the dorsalmost possibly forming a pointed or flat anterior projection; alveoli and/ or transverse ridges possibly present. Radioles arranged in spirals ( 1 to 8 whorls) in larger species and semicircles in smaller species. Inter-radiolar membrane present. Radiolar photoreceptors absent or various types: simple ocelli, paired or individual ocellar clusters, depending on the taxon. Mouth palps present. Peduncle generally broader than radioles, triangular in cross-section, with distal wing-like projections; constriction between peduncle and opercular ampulla may be present; peduncle inserted left to midline of prostomium. Operculum composed of a basal ampulla as inverted or flattened cone; calcareous reinforcement forming a flattened endplate, thorns may be present. Simple ocelli possibly present in the basal ampulla. Thorax formed by collar and six posterior segments. Collar tri-lobate, chaetigerous or, possibly, achaetous. Tonguelets present between the dorso-lateral lobes and the mid-ventral lobe. Thoracic membrane continuous with dorso-lateral lobes extending throughout the thorax and forming ventral apron over anterior abdominal region. Spirobranchus collar chaetae and/or limbates. Limbate thoracic notochaeta; Saw-shaped thoracic uncini (rasp-shaped in some taxa), anterior main peg bent downwards, gouged. Thoracic tori ending ventrally apart in anterior region and closer in posterior region, forming a ventral thoracic triangular depression. Abdominal uncini similar to thoracic ones. True trumpet-shaped abdominal neurochaetae, distally bent, with 2 distal rows of denticles and a pointed lateral process. Progressively longer neurochaetae along abdomen. Ventral glandular shields present.

\section{Spirobranchus lirianeae sp. nov.} (Figs. 2-4, 9)

Examined material: Rio de Janeiro state, Itha Grande Bay, Angra dos Reis Municipality: Machado Beach: $\quad 23^{\circ} 00^{\prime} 11.21^{\prime \prime} \mathrm{S}, \quad 44^{\circ} 15^{\prime} 24.82^{\prime \prime} \mathrm{W}$, intertidal, MNRJP-002777 (1 specimen). Cataguases Island: $23^{\circ} 01^{\prime} 28.57^{\prime \prime} \mathrm{S}, 44^{\circ} 17^{\prime} 06.52^{\prime \prime} \mathrm{W}$, intertidal, MNRJP-002774, MNRJP-002775, MNRJP-002776 (10 specimens, including holotype). Holotype: MNRJP-002774 - Cataguases Island, preserved entire, with tube, 16 May 2019, under rocks. Paratypes: MNRJP-002775, MNRJP-002776, MNRJP-002777, 10 specimens.

Diagnosis: Tubes solitary with one longitudinal pointed keel and transverse ridges. Operculum and calcareous endplate funnel-shaped, without thorns or spines. Paired reddish ocellar clusters along aboral face of radioles. Collar chaetae absent. Tonguelets bilobed, one lobe bearing finger-like processes.

\section{Description}

Tube: Opaque, white purplish or blueish, internally blueish. Triangular in cross-section, lumen circular. One longitudinal keel along the tube, extending over the opening forming a pointed tip. Transversal ridges present on tube surface (Fig. 2C). Tubes solitary.

Radiolar Crown: Live and preserved specimens with dark brown base of crown, then alternating bands of white, iridescent pigmentation and light brown pigmentation, in a "zebra-like" pattern (Fig. 2A). Coloration faded after preservation. Crown composed of two lobes arranged in a complete circle, each with around 15 radioles, basally joined by inter-radiolar membrane for one third of their length, dorsally hidden by collar lobes and operculum (Fig. 2B). Radioles rectangular in cross-section, the inner side with two rows of filiform pinnules, distally shorter, with naked tips. Tips filiform and about same size as distal pinnules. Dorsal radioles longer than ventral ones. Paired red spots present, 3 to 6 pairs per radiole (Figs. 2D, 2E), with ocellar clusters (Fig. 2E). 
Mouth Parts: Two thin, smooth lips. Dorsal lips with median notch and forming a pair of lateral filiform palps, often colored in brown, about as long as proximal pinnules. Ventral lips rectangular, as semicircular lap along inner sides of bases of radiolar lobes.

Peduncle: Smooth, triangular in cross-section, inserted slightly left to mid-dorsal line. Pair of smooth lateral wings, triangular with rounded tip, not reaching tip of operculum. "zebra-like" coloration pattern present, extending into the lateral wings (Figs. 2B, 2G). Constriction between peduncle and opercular base absent.

Operculum: Continuous with the peduncle (Fig. 2G). Opercular ampulla funnel-shaped, with calcareous opercular endplate, deeply concave, without ornamentation, white, circular in top view (Figs. 2A, 2F, 2G, 3A, 3D, 4A, 4B, 4C). Talon embedded in opercular ampulla, basally ending in five rounded teeth, unequal in size (Fig. 2G).

Collar and Thoracic Membranes: High, three-lobed collar extending to margin of inter-radiolar membrane. Dorso-lateral lobes long, circular with entire edges, reaching near distal region of crown; continuous with thoracic membranes, forming ventral apron covering 1 to 2 abdominal chaetigers. Mid-ventral lobe reniform, laterally as long as dorsolateral lobes, shorter medially, often folded, inserted between crown lobes (Fig. 2A, 2H). Tonguelets present between lateral and ventral lobes; bilobed, outer lobe and inner lobe leaf-shaped, the former twice as long, with fringed rim (Fig. 9A, 9B). Collar light brown or darker, purplish brown, extending through entire thorax, iridescent inclusions present in median-ventral lobe (Fig. 3B).

Thorax: Six chaetigers. Collar chaetae absent in adults (Fig. 3C), juveniles not observed. Notopodial lobes conical, emerging between thoracic membranes and neuropodia. Thoracic chetae limbate, in two fascicles of different lengths per notopodium (Fig. 4D). Neuropodial lobes rectangular, overlapping subsequent neuropodia, all bearing straight tori of similar size along the thorax. Thoracic uncini saw-shaped, with 9-10 curved teeth, plus the anterior-most peg, flat, spatulated (Fig.4E). Parapodial lobes approaching each other posteriorly, forming a ventral triangular depression. Glandular clusters covering the ventral portion of mid-ventral collar lobe, as a rectangle; glandular rectangles also present basally to thoracic

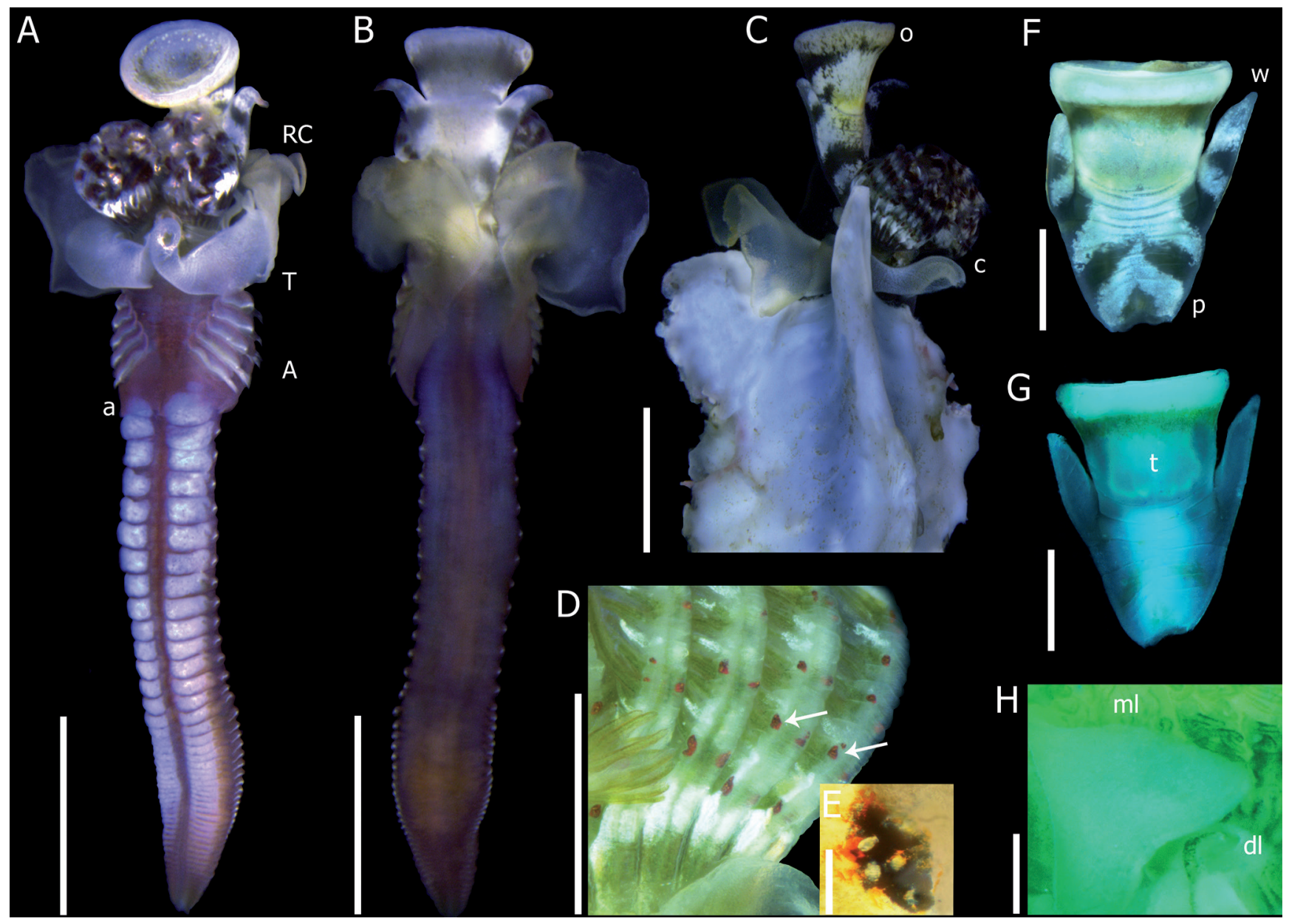

Figure 2. Spirobranchus lirianeae sp. nov. (A-C) Holotype (MNRJP-002774); (D-E, H) Paratype (MNRJP-002775); (F-G) Paratype (MNRJP 002777). (A) entire worm, ventral view, (B) dorsal view, (C) anterior end of tube, with exposed operculum, collar lobes and crown, (D) bases of radioles, with paired compound ocellar clusters, (E) detail of a ocellar cluster, (F) operculum, dorsal view, (G) operculum clarified with glycerin, exposing talon, $(\mathrm{H})$ internal crown, with folded mid-ventral lobe and dorsal lip. Scale bars $=1 \mathrm{~mm}(\mathrm{~A}, \mathrm{~B}, \mathrm{C}), 0,2 \mathrm{~mm}(\mathrm{D}, \mathrm{F}, \mathrm{G}), 50 \mu \mathrm{m}(\mathrm{H}), 3 \mu \mathrm{m}(\mathrm{E}) . \mathrm{A}=$ abdomen; $\mathrm{a}=$ apron; $\mathrm{C}=$ collar; $\mathrm{dl}=$ dorsal lip; $\mathrm{ml}=$ mid-ventral lobe; $0=$ operculum; $\mathrm{p}=$ peduncle; $\mathrm{RC}=$ radiolar crown; $\mathrm{t}=$ talon; $\mathrm{T}=$ thorax; $\mathrm{w}=$ wings. Arrows pointing compound ocellar clusters. 
neuropodial tori and in ventral depression, as 3 to 4 pairs of ventral glandular shields (Fig. 3D).

Abdomen: Largest analyzed specimen with 46 abdominal segments, at least the first one achaetous. Abdomen usually three times longer than thorax, with larger anterior chaetigers (Fig. 3E), the final third with densely packed, much shorter chaetigers (Fig. 3F). Notopodial uncini smaller than thoracic ones, saw-shaped, with 10-13 teeth plus gouged anterior peg (Fig. 4F). Neuropodial chaetae true trumpet-shaped, abruptly bent, with 2 distal rows of denticles separated by groove and lateral filiform projection, serrated with minute teeth (Fig. 4G). Color equal to thorax, possibly darker or reddish on dorsum, and beige to brown on venter, with squared ventral shields anteriorly and rectangular posteriorly. Glandular clusters present basally to tori and on posterior abdomen, near fecal sulcus rim (Fig. 3G). Pygidium bilobed, with terminal anus.

Remarks: Bastida-Zavala (2008) studied specimens of Panama's Pacific coast and mentioned a possible different species ("Pomatoleios sp."), with a prominent opercular talon. This species, although never formally described, presents only a longitudinal keel in the tube, differing from S. lirianeae sp. nov. because the specimens analyzed for the present study do not possess thoracic ocelli as the individuals studied by Bastida-Zavala (2008) do.
Although the $S$. cf. kraussii specimens reported from Costa Rica are possibly a different species within the S. kraussii-complex, they share many morphological similarities with $S$. lirianeae sp. nov., but they are distinguished by having flattened projection of the dual tube keels, while members of Spirobranchus lirianeae sp. nov. possess a tube with a single sharp longitudinal keel. Moreover, S. cf. kraussii and S. kraussii are gregarious, belt-forming species, whereas animals belonging to S. lirianeae sp. nov. exhibited a low density of individuals in the sampled areas. Both S. kraussii and the Costa Rican morphospecies present dark brown paired spots on the radioles, associated with photoreceptor structures, whereas those of members of S. lirianeae sp. nov. are red. The funnel-like calcareous endplate of the operculum of individuals of S. lirianeae sp. nov. exhibits a deeper concavity than those of other members of the other species within the S. kraussii complex. The opercular talon is short in members of S. cf. kraussii and S. kraussii, and long in S. lirianeae sp. nov., almost fully immersed within the basal opercular ampulla. The opercular talon of specimens of S. lirianeae sp. nov. ends in five round and unequal teeth, similar to those reported for members of S. kraussii, in the redescription by Simon et al. (2019). The tonguelets of members $S$. cf. kraussii and S. lirianeae sp. nov. are different, being pyriform in the former and bilobed, with fringed outer lobe in the latter. Furthermore,
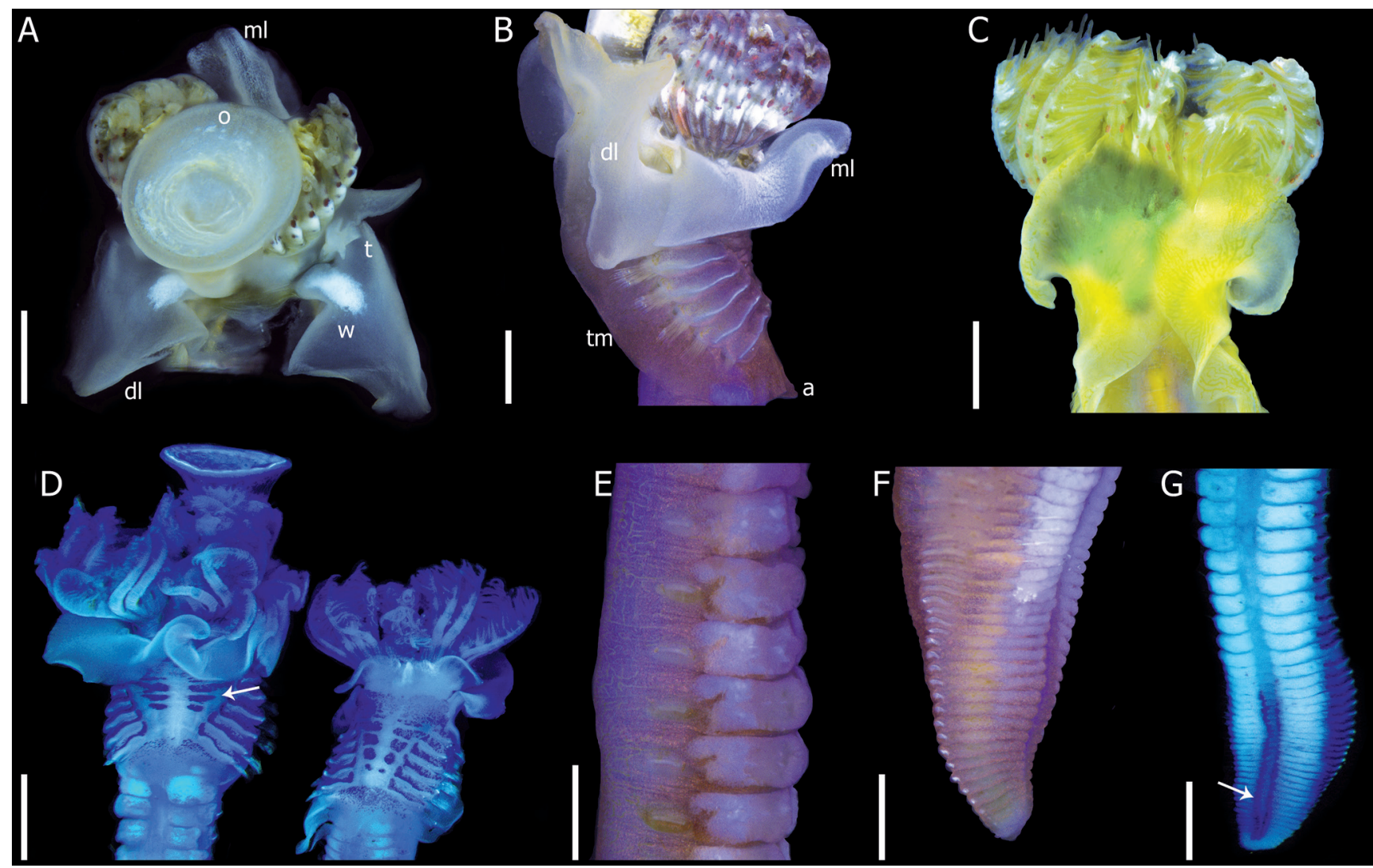

Figure 3. Spirobranchus lirianeae sp. nov. (A, C, D) (righ hand image), Paratype (MNRJP-002775); (B, D) (left hand image), (E-G) Holotype (MNRJP-002774). (A) anterior end, superior view, (B) thorax, lateral view, (C) anterior end, dorsal view, showing collar dorso-lateral lobes (D) anterior end, through beginning of abdomen, ventral view, stained with methylene blue, $(E)$ anterior abdominal chaetigers, lateral view, (F) posterior end, ventro-lateral view, (G) posterior end, ventral view, stained with methylene blue. Scale bars $=0,2 \mathrm{~mm}(\mathrm{~A}, \mathrm{~B}, \mathrm{C}, \mathrm{D}, \mathrm{E}, \mathrm{F}, \mathrm{G}) . \mathrm{a}=$ apron; $\mathrm{dl}=$ dorso-lateral lobe; $\mathrm{ml}=$ mid-ventral lobe; $0=$ operculum; $\mathrm{t}=\mathrm{tonguelet} ; \mathrm{tm}=$ thoracic membrane; $W=$ wing. Arrows pointing glandular regions. 
members of S. cf. kraussii have six pairs of thoracic ventral shields, whereas in those of S. lirianeae sp. nov. there are only three or four pairs. The shape of the tonguelets and the ventral shields of members of S. kraussii were not defined in the redescription of Simon et al. (2019), although the images in that report show the tonguelets are not fringed.

Members of S. lirianeae sp. nov. differ from those belonging to the recently described $S$. sinuspersicus in having an operculum with a concavity as a deep funnel, with a talon formed by five protuberances, while in individuals of $S$. sinuspersicus the operculum is flattened (though slightly concave) and the talon has two or three protuberances. The compound ocellar clusters of members of S. sinuspersicus are dark brown, whereas in S. lirianeae sp. nov. they are red, notwithstanding the brown bands on the crown. Animals belonging to S. sinuspersicus present bilobed tonguelets with smooth lobes (not described, but see Pazoki et al., 2020, fig. 4E), unlike the unique fringed outer lobe of members of S. lirianeae sp. nov. Moreover, S. sinuspersicus was indicated as invasive in potential (Pazoki et al., 2020), since individuals were found forming aggregates on artificial substrates, which also differentiates it from S. kraussii, another gregarious species. We only observed individuals of S. lirianeae sp. nov. on natural substrates, despite sampling artificial substrates in the type locality, including buoys, small boats, metal pipes, and wooden piers. Since Simon et al. (2019) established that species belonging to the S. kraussii complex are regionally distributed species, given the morphological differences between our specimens and members of the other species assigned

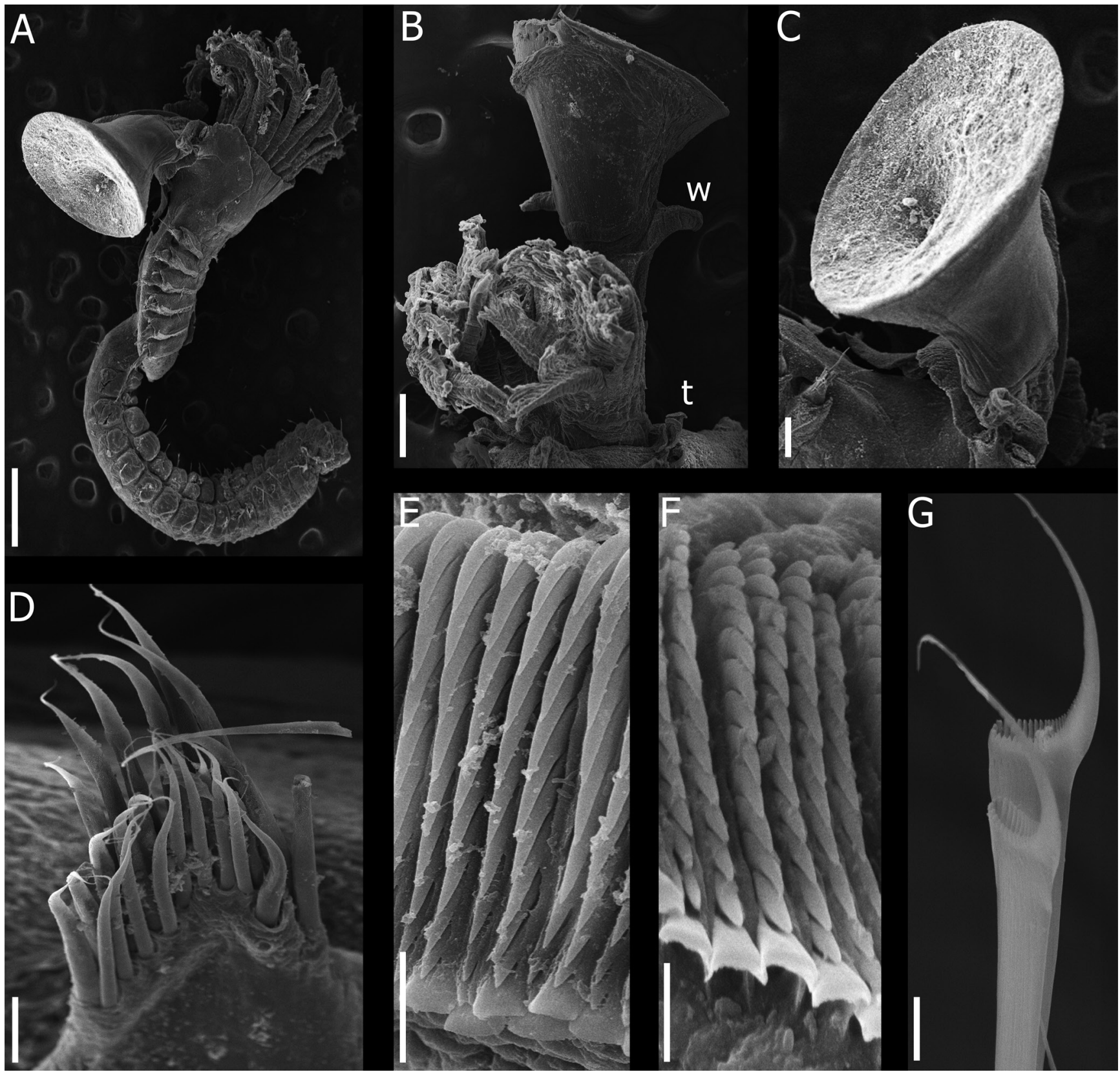

Figure 4. SEM images of Spirobranchus lirianeae sp. nov. Paratype (MNRJP-002776). (A) entire worm, lateral view, (B) crown and operculum, ventral view, (C) detail of operculum, (D) thoracic limbate notochaetae, (E) thoracic uncini, (F) abdominal uncini, (G) abdominal neurochaetae. Scale bars $=500 \mu \mathrm{m}(\mathrm{A}), 200 \mu \mathrm{m}(\mathrm{B}, \mathrm{C})$, $20 \mu \mathrm{m}(\mathrm{D}), 10 \mu \mathrm{m}(\mathrm{E}), 5 \mu \mathrm{m}(\mathrm{F}, \mathrm{G}) . \mathrm{t}=$ tonguelet; $\mathrm{w}=$ wing. 
to that species complex (in addition to the morphotype S. cf. kraussii, reported from Costa Rica), we assert that the material described herein corresponds to a new species.

The concave and tapered calcareous operculum, the presence of paired compound ocellar clusters along the radioles, the tonguelets with a fringed lobe, and the absence of collar chaetae render S. lirianeae sp. nov. unique among Brazilian species of Spirobranchus. Although the operculum of S. minutus also lacks endplate ornamentation, the structure is convex and bilobed, not tapered as in members of $S$. lirianeae sp. nov. Moreover, specimens of S. minutus do not present radiolar photoreceptor structures, such as those of members of S. lirianeae sp. nov., and their tubes are multi-keeled and ornamented by alveoli, whereas the tube of members of S. lirianeae sp. nov. is single-keeled and lacks alveoli. The tube of members of $S$. giganteus is also single-keeled, but their operculum is elaborately ornamented with spined thorns. Individuals of S. giganteus have single compound ocellar clusters, which are located only at the base of the two dorsal-most radioles. Members of $S$. tetraceros have fringed interradiolar processes and collar chaetae, both characters absent among members of S. lirianeae sp. nov. The operculum of specimens of S. tetraceros also presents complex ornamentation and the ocelli of those animals are simple.
Type-locality: Cataguases Island, Ilha Grande Bay, Rio de Janeiro, Brazil (Atlantic Ocean).

Habitat: Intertidal: Under rocks; not found in artificial substrates.

Etymology: The specific epithet is a tribute to Professor Liriane Monte Freitas, from the Universidade Federal de Alagoas (Federal University of Alagoas), responsible for the formation of numerous biologists, including the first author.

Distribution: Atlantic Ocean: Brazil, State of Rio de Janeiro, in Cataguases Island and Angra dos Reis (Ilha Grande Bay).

\section{Spirobranchus giganteus (Pallas, 1766)}

(Figs. 5, 8, 9)

Serpula gigantea Pallas, 1766.

Spirobranchus (Cymospira) giganteus (Pallas, 1766). Blainville, 1828.

Olga elegantissima Jones, 1962.

Spirobranchus giganteus giganteus (Pallas, 1766). ten Hove (1970).

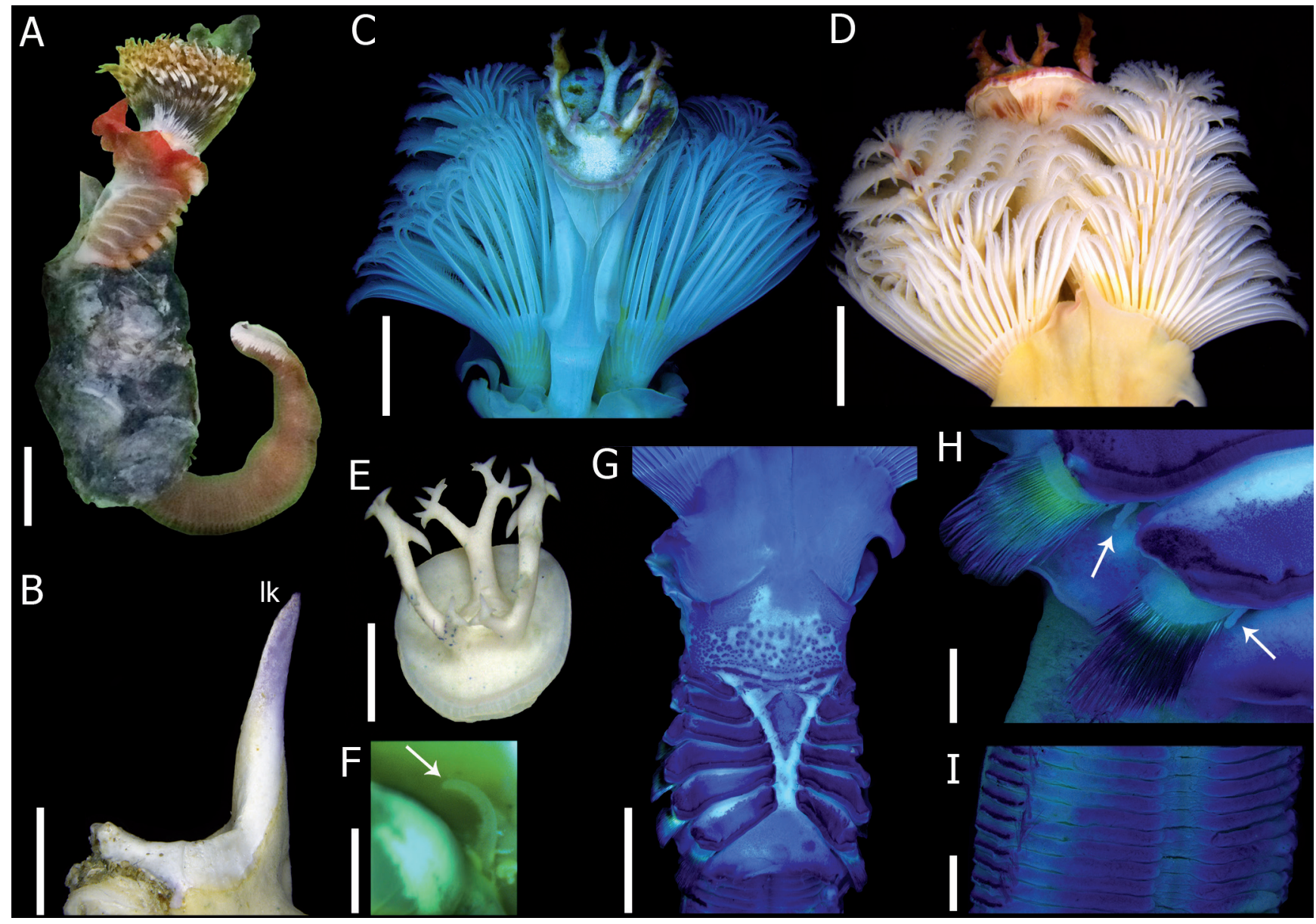

Figure 5. Spirobranchus giganteus (MNRJP-002778). (A) entire worm, inside fragment of tube, lateral view, (B) anterior end of tube, (C) operculum and radiolar crown, dorsal view, (D) same as $C$, ventral view, $(E)$ operculum, superior view, $(F)$ base of crown, exposing oral palp, $(G)$ thorax, ventral view, stained with methylene blue, $(\mathrm{H})$ thoracic notopodia, $(\mathrm{I})$ anterior abdominal chaetigers Scale bars $=1 \mathrm{~mm}(\mathrm{~A}, \mathrm{~B}, \mathrm{C}, \mathrm{D}, \mathrm{E}, \mathrm{G}), 0,3 \mathrm{~mm}(\mathrm{I}), 0,2 \mathrm{~mm}(\mathrm{H}), 0,1 \mathrm{~mm}(\mathrm{~F})$. Ik = longitudinal keel. Arrows pointing the oral palp (F) and parapodial cirri (H). 
Spirobranchus giganteus. ten Hove (1994); Bastida-Zavala (2009); Bastida-Zavala \& Salazar-Vallejo (2000).

Examined material: 29 specimens. Brazil: Alagoas state, Marechal Deodoro Municipality: Frances sandstone reef: $09^{\circ} 46^{\prime} 16.02^{\prime \prime}$ S, $35^{\circ} 50^{\prime} 18.57^{\prime \prime} \mathrm{W}$, MNRJP-002778 (4 specimens). Saco da Pedra sandstone reef: $09^{\circ} 44^{\prime} 38.20^{\prime \prime} S$, $35^{\circ} 49^{\prime} 08.71$ "W, MNRJP-002779 (16 specimens). Bahia state: Abrolhos Archipelago, Siriba Island: $17^{\circ} 58^{\prime} 07^{\prime \prime}$, $38^{\circ} 42^{\prime} 46^{\prime \prime} \mathrm{W}, 3 \mathrm{~m}$, IBUFRJ0007 (7 specimens). Revizee/ score-Central Project $17^{\circ} 02^{\prime} 31.20^{\prime \prime} \mathrm{S}, 37^{\circ} 36^{\prime} 28.79^{\prime \prime} \mathrm{W}$, $50 \mathrm{~m}$, IBUFRJ3140 (4 specimens). Espírito Santo state: Revizee/score-Central Project $20^{\circ} 09^{\prime} 03.59^{\prime \prime}$, $37^{\circ} 28^{\prime} 47.99^{\prime \prime} \mathrm{W}$, IBUFRJ3139 (2 specimens). Panama: 34 specimens. Caribbean Sea, San Blás Archipelago: $09^{\circ} 34^{\prime} 37.2^{\prime \prime} \mathrm{N}, 78^{\circ} 53^{\prime} 06^{\prime \prime} \mathrm{W}, 50 \mathrm{~m}$, IBUFRJ4092 (15 specimens). $09^{\circ} 34^{\prime} 37.20^{\prime \prime} \mathrm{N}, 78^{\circ} 53^{\prime} 60^{\prime \prime} \mathrm{W}, 50 \mathrm{~m}$, IBUFRJ4093 (10 specimens). $09^{\circ} 34^{\prime} 37.20^{\prime \prime} \mathrm{N}, 78^{\circ} 53^{\prime} 60^{\prime \prime} \mathrm{W}, 50 \mathrm{~m}$, IBUFRJ4094 (9 specimens).

Diagnosis (modified from Jones, 1962): Operculum possessing two dorsal thorns with prominent spines; mid-ventral thorn often present, smaller, dichotomously branching distally. Radiolar crown arranged in spirals of up to 8 whorls.

\section{Description}

Tube: Opaque, white or blueish. Triangular in cross-section, lumen circular. One longitudinal keel along the tube, extending over the opening forming a pointed tip (Fig. 5B). Tubes solitary.

Radiolar Crown: Live specimens with irregular bands of coloration, varying from white, beige and blue to pink, yellow, orange or red (Fig. 5A), sometimes multiple colors unequally mixed in each lobe; pattern in coloration absent. Coloration faded after preservation, only darker shades remaining. Crown composed of two lobes arranged in spirals with 2-8 whorls, each with up to 200 radioles, basally joined by inter-radiolar membrane for one third of their length (Figs. 5C, 5D). Radioles rectangular in cross-section, inner side with two rows off filiform pinnules, distally shorter, with naked tips. Tips filiform and about same size as proximal pinnules. Dorsal radioles longer than ventral ones. Single ocellar cluster forming a compound eye in a dorsal concavity at each of pair of dorsal most radioles.

Mouth Parts: Two thin, smooth lips. Dorsal lips with median notch and forming a pair of lateral filiform palps, about same length as proximal pinnules (Fig. 5F). Ventral lip rectangular, forming internal lap along base of radiolar lobes.

Peduncle: Smooth, triangular in cross-section, inserted slightly left to crown midline. Pair of smooth lateral wings forming near base of peduncle, rectangular, with rounded edge, not extending beyond operculum (Fig. 5C). Constriction at base of operculum absent. Coloration pattern usually not extending into the lateral wings, but often with vertical bands along opercular rim.

Operculum: Continuous with the peduncle. Opercular ampulla flat, circular in top view, with flat calcareous endplate, generally white, also circular when seen from the top. Two horn-like, symmetrical thorns originating at center of the endplate and projecting dorsolaterally; spines bearing multiple thorns, some with smaller spines. Single ventral spine often present, branching dichotomously at the distal end, also with thorns (Fig. 5E). Talon absent.

Collar and Thoracic Membranes: Three-lobed collar. Dorso-lateral lobes shorter, circular, with entire edges, reaching near proximal region of crown; continuous with thoracic membranes, forming ventral apron covering 2 to 3 abdominal chaetigers. Mid-ventral lobe petaloid, longer than dorso-lateral lobes, with wide, round lateral rim and triangular median rim with pointed tip, often folded medially, inserted between crown lobes. Tonguelets present between dorso-lateral and ventral lobes (Figs. 9C, 9D), united to dorso-lateral lobes by circular fold; tonguelets trilobed, with two outer lobes: dorsal outer lobe larger, round, with waved rim, ventral outer lobe also round, smaller than dorsal, with smooth rim; inner lobe half the length of external lobes, circular, with smooth rim (Fig. 9D). Collar lobes frequently red, pigmentation extending through anterior thorax.

Thorax: Seven chaetigers. Collar chaetae as Spirobranchus-type and limbate chaetae, disposed in one fascicle (Figs. 8A, 8B). After collar, notopodial lobes conical, emerging between thoracic membranes and neuropodia. Thoracic chetae limbate, in three fascicles of different lengths per notopodium (Fig. 8C, 8D). Neuropodial lobes rectangular, all bearing straight tori of similar size through thorax (Fig. 5G). Digitiform cirri present at notopodial base (Figs. 5H, 8C). Thoracic uncini saw-shaped, with 19-23 curved teeth, plus gouged anterior-most peg (Fig. 8E). Parapodial lobes approaching each other posteriorly, forming a ventral triangular depression. Glandular clusters covering ventral portion of mid-ventral collar lobe, forming one pentagonal and two straight inferior bands, also covering all thoracic neuropodia, except for origin of tori, and in ventral depression, as single ventral glandular pad, spoon-shaped.

Abdomen: Largest analyzed specimen with 125 abdominal segments. Abdomen in entire animals usually five times longer than thorax, with larger anterior chaetigers (Fig. 5I), the final third abruptly with densely packed chaetigers. Notopodial uncini smaller than thoracic ones, saw-shaped, with 13-16 teeth plus gouged anterior peg (Fig. 8F). Neurochaetae as true trumpet-shaped chaetae, abruptly bent, with 2 distal rows of denticles separated by groove and a filiform lateral projection, serrated by minute teeth (Fig. 8G). Ventral shields squared anteriorly and rectangular posteriorly. Glandular clusters present basally to tori. Pygidium bilobed, with terminal anus. 
Remarks: The distribution of S. giganteus, previously considered circumtropical, has been questioned lately, as for many other "circuntropical" or "cosmopolitan" annelid taxa (Nygren, 2014; Hutchings \& Kupriyanova, 2018). ten Hove (1970) considered the morphospecies forming the S. giganteus complex as subspecies, but later elevated them to separate complexes, nested within the S. giganteus sensu latu complex (ten Hove, 1994). Thus, as reported by Fiege \& ten Hove (1999), two species complexes are recognized in the Atlantic Ocean, S. polycerus (Schmarda, 1861) and S. giganteus sensu stricto, this latter consisting of S. giganteus (Pallas, 1766), S. incrassatus Mörch, 1863 and S. spinosus Moore, 1923. However, S. incrassatus and S. spinosus were originally described from the Pacific Ocean and their occurrence in the Atlantic is unlikely; also, the opercula of members in these latter two species are either ornamented with long and slender, often hornlike thorns, or with much smaller structures, pointed and normally thicker, called spines; usually, the thorns have spines along the axis. In S. giganteus there are two slender horn-like thorns and frequently a third thorn, bifurcated near the distal end, whereas those of members of S. incrassatus have two thicker thorns next to a third one, bifurcated near the base. Members of $S$. spinosus have opercula with five thick and short spines. According to information from the WoRMS database, only specimens from the Caribbean region should be identified as S. giganteus (Read, 2020). Apart from the original description (Pallas, 1766) and that provided by Mörch (1863), the main source for identification of S. giganteus is the revision by ten Hove (1994), which does not provide a diagnosis. Instead, the diagnosis of Olga elegantissima, by Jones (1962), is the closest to S. giganteus, since Pallas's original description (1766). In the present work, since specimens of S. giganteus were identified based on comparisons with several individuals from San Blás, in the Caribbean, and the animals were morphologically identical to those found in Alagoas, Bahia and Espírito Santo, we confirm the presence of this species off Brazilian shoreline.

Spirobranchus giganteus is the only Brazilian species of Christmas-tree-worm, those which radiolar lobes form pine tree-shaped spirals. Moreover, the notopodial cirrus found on thoracic chaetigers of our members of this species has not been described for any other species of serpulids. The presence of special collar chaetae and opercular ornamentation distinguish members of S. giganteus from specimens of S. minutus and S. lirianeae sp. nov., in which both these characters are absent. The most similar species to S. giganteus in Brazil is S. tetraceros, with which it was previously synonymized (Dew, 1959). Brazilian specimens of $S$. tetraceros were actually identified as belonging to S. giganteus by Skinner et al. (2012), in part of the material used for that study, but that mistake was corrected by Perry et al. (2017). The operculum of specimens of S. tetraceros has a conical endplate, or up to four branched concentric thorns (ten Hove, 1970; Rodrigues et al., 2020), whereas that of members of S. giganteus has two dorsolateral thorns and, frequently, a bifurcated mid-ventral thorn. Furthermore, whereas animals belonging to S. giganteus have individual compound eyes at the base of each dorsal-most radiolus, members of S. tetraceros only have simple ocelli scattered along the radioles and they present interradiolar processes, which are absent among members of S. giganteus.

Type-locality: Curaçao, Caribbean Sea (Atlantic Ocean).

Habitat: Intertidal: associated to scleractinian corals (Cnidaria: Anthozoa: Scleractinia) and Milleporidae hidrocorals (Cnidaria: Hydrozoa); rarely found without coral association (Skinner et al., 2012).

Distribution: Atlantic Ocean: Gulf of México, Caribbean Sea and Brazil, in the states of Pernambuco (Zibrowius, 1970), Alagoas (Correia \& Sovierzoski, 2009), Bahia (Rullier \& Amoureux, 1979; Santa-Isabel et al., 2000), Rio de Janeiro (Skinner et al., 2012) and Espírito Santo (present paper).

\section{Spirobranchus minutus (Rioja, 1941) (Figs. 6, 8, 9)}

Pomatoceros minutus Rioja, 1941.

Pomatoceros minutus. Bastida-Zavala \& Salazar-Vallejo (2000); Bastida-Zavala (2008).

Serpulorbis catella Weisbord, 1962.

Spirobranchus minutus. Bastida-Zavala et al. (2017).

Examined material: 67 specimens. Alagoas state, Maceió Municipality: Garça Torta reef: 09³4'55.72"S, $35^{\circ} 39^{\prime} 22.56^{\prime \prime}$ W, MNRJP-002780 (6 specimens). Ipioca Reef: 09³0'54.08"S, 35³5'11.64"W, MNRJP-002781 (1 specimen). Marechal Deodoro Municipality: Frances sandstone reef: $09^{\circ} 46^{\prime} 16.02^{\prime \prime} \mathrm{S}, 35^{\circ} 50^{\prime} 18.57^{\prime \prime} \mathrm{W}$, MNRJP-002782 (11 specimens). Rio de Janeiro state, Armação dos Búzios Municipality: Geribá Beach: 2246'50.62"S, 4154'14.59"W, MNRJP-002783 (8 specimens). Santa Catarina state, Florianopolis Municipality: Daniela

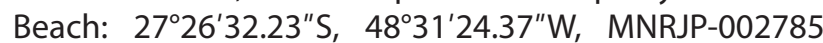

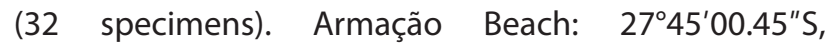
48 $30^{\prime} 01.91^{\prime \prime} \mathrm{W}, \mathrm{MNRJP}-002786$ (5 specimens). Pantano do Sul: $27^{\circ} 47^{\prime} 01.06^{\prime \prime} S$, 48³0'24.69"W, MNRJP-002784 (4 specimens).

Diagnosis (after Bastida-Zavala et al., 2017): Tube white, with three longitudinal keels and rows of alveoli between keels; without peristomes. Opercular peduncle with thin distal wings, white. Operculum conical, with calcareous distal plate, with rounded tip. First notopodium with 2-3 limbate collar chaetae, but sometimes lacking collar chaetae altogether, with glandular spot in position of collar chaetae.

\section{Description}

Tube: Opaque, white, or pinkish. Triangular in cross-section, lumen circular. Three longitudinal keels along the tube, extending over the opening forming pointed tips. Two longitudinal rows of alveoli present between the keels (Fig. 6B). Tubes solitary. 
Radiolar Crown: Live specimens with alternating bands of brown pigment and non-pigmented areas. Base of crown usually dark brown (Figs. 6C, 6F). Coloration faded after preservation (Fig. 6A). Crown composed of two lobes arranged in semicircles, each with 10 radioles, basally joined by inter-radiolar membrane for one third of their length. Radioles cylindric in cross-section, inner side with two rows of filiform pinnules of even length through radioles, with naked tips. Tips filiform and about as long as pinnules. Ocelli absent.

Mouth Parts: Two thin, smooth lips. Dorsal lips shorter than ventral lip, as pair of lateral digitiform palps, about half as long as pinnules. Ventral lips longer, rectangular, connecting both radiolar lobes at base of radiolar crown.

Peduncle: Smooth, triangular in cross-section, inserted slightly left to dorsal mid-line. Pair of smooth lateral wings at tip of peduncle, triangular, not extending beyond operculum (Figs. 6A, 6C). Constriction between peduncle and opercular base conspicuous. Dark brown pigmentation as lateral spots on peduncle, not extending into distal wings.

Operculum: Opercular ampulla round-shaped, distally flat, circular in top view, with flat to convex calcareous endplate, generally white or purplish, bilobed (Fig. 6D) with dorsal edge pointed (Fig. 6E). Talon absent.

Collar and Thoracic Membranes: Three-lobed collar. Dorso-lateral lobes twice as long as mid-ventral lobe, triangular, with entire edges, reaching near base of crown; continuous with thoracic membranes, forming a ventral apron covering 2 abdominal chaetigers. Mid-ventral lobe rectangular. Tonguelets present between dorso-lateral and ventral lobes, thin, leaf-shaped, often brown colored (Figs. 6C, 9E, 9F).

Thorax: Six or seven chaetigers, depending on presence of collar chaetae. Collar chaetae limbate or absent. After collar, notopodial lobes conical, emerging between thoracic membranes and neuropodia. Thoracic chetae limbate, longer than collar chaetae, in one fascicle (Fig. $8 \mathrm{H}$ ). Neuropodial lobes rectangular, all bearing tori curved downwards, gradually smaller through thorax. Thoracic uncini saw-to-rasp-shaped, with 8-10 rows of curved teeth in profile, general formula $=p: 4: 3: 2: 2: 2: 1: 1: 2: 1$, peg flat and squared. Posterior teeth larger than anterior ones (Fig. 8I). Parapodial lobes not approaching each other posteriorly, thus not forming a ventral triangular depression. Glandular clusters as scattered spots in neuropodia, 6 pairs of trapezoidal glandular thoracic shields, leaving longitudinal mid-ventral gap (Fig. 6F).

Abdomen: Largest analyzed specimen with 18 abdominal segments. Abdomen in entire animals usually three times longer than thorax, with chaetigers progressively more densely packed posteriorly region. Notopodial uncini smaller than thoracic ones, rasp-shaped, with 10-12 rows of curved teeth in profile, general formula $=p: 7: 6: 5: 5: 4: 4: 4: 4: 5: 4: 3: 2$, anterior peg squared (Fig. 8J). Neuropodial chaetae true trumpet-shaped, abruptly bent, with 2 distal rows of denticles separated by groove and lateral serrated filiform projection (Fig. 8K). Glandular

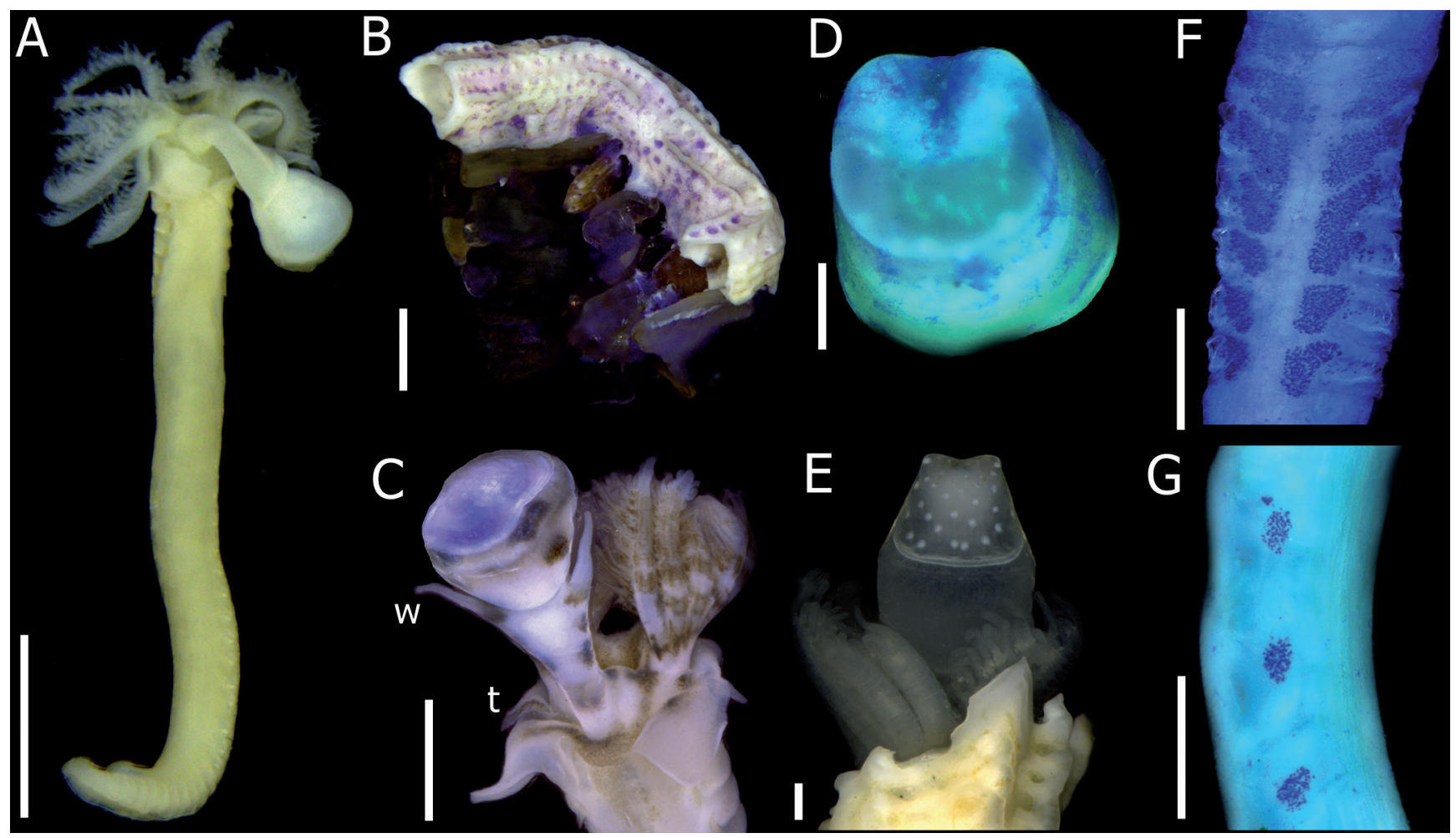

Figure 6. Spirobranchus minutus. (A) MNRJP-002780; (B-C, E) MNRJP-002783; (D, F, G) MNRJP-002785. (A) entire worm, dorsal view, (B) tube, (C) anterior end, dorsal view, (D) operculum, superior view, (E) operculum in juvenile, dorsal view, (F) thorax (except collar), ventral view, stained with methylene blue, (G) anterior abdominal chaetigers, lateral view, stained with methylene blue. Scale bars $=1 \mathrm{~mm}(\mathrm{~A}), 500 \mu \mathrm{m}(\mathrm{B}), 200 \mu \mathrm{m}(\mathrm{C}), 100 \mu \mathrm{m}(\mathrm{F}, \mathrm{G}), 50 \mu \mathrm{m}(\mathrm{D}, \mathrm{E}) . \mathrm{t}=$ tonguelet; $\mathrm{w}=$ wing. 
clusters present (Fig. 6G) basally to tori. Pygidium bilobed, with terminal anus.

Remarks: The flattened and ventrally elongated opercular plate of members of $S$. minutus may render the distinction between these animals and members of both the congeneric S. americanus (Day, 1973) and S. triqueter (Linnaeus, 1758) problematic. Spirobranchus americanus was described from animals from the Beaufort region of North Carolina (USA) (Day, 1973). The absence of a bilobed distal end on the ventral opercular face and the single-keeled tube of those animals differentiate them from specimens of S. minutus. In the original description of S. americanus, Day (1973) reports and illustrates opercular variations similar to those observed in members of S. minutus, although his illustrations demonstrate that calcareous reinforcement occurs in the most basal portion of the opercular ampulla and forms a diagonal line in transverse view of the operculum. Bastida-Zavala et al. (2017) also report that individuals of S. americanus have more rows of alveoli on the sides of their tubes than among S. minutus. Spirobranchus triqueter was originally described and reported from the European Atlantic coast (Linnaeus, 1758). The operculum of those animals has three characteristic pointed projections distally and their tubes are single-keeled, unlike the triple-keeled tube of members of S. minutus, which also lack such opercular projections. Çinar (2013) does not mention S. minutus as an introduced species, but there are multiple reports of this species beyond the Pacific Ocean (Zibrowius, 1970; Morgado, 1980; Souza, 1989; Rocha, 1993, 1995; Ananias, 2017). The specimens we analyzed for the present study are morphologically identical to others reported from Brazil (Zibrowius, 1970; Ananias, 2017) and further afield (Rioja, 1941; Bastida-Zavala \& Salazar-Vallejo, 2000; Bastida-Zavala, 2008, 2009).

The absence of calcareous projections in the operculum, radiolar photoreceptor structures and special collar chaetae render members of $S$. minutus immediately distinguishable from those of S. giganteus and S. tetraceros. Individuals of both S. minutus and S. lirianeae sp. nov. share the absence of opercular projections, but among members of $S$. minutus the operculum is slightly convex and bilobed, photoreceptor structures are absent, and their tubes are triple-keeled, with rows of alveoli. By having rasp-shaped uncini and simple (rather than lobed) tonguelets, individuals of $S$. minutus can be differentiated from specimens of the other species of the genus recorded in Brazil.

Type-locality: Acapulco, Guerrero, Mexico (Pacific Ocean).

Habitat: Intertidal: on rocky shores, beneath rocks.

Distribution: Considered as amphiamerican by BastidaZavala et al. (2017). Pacific Ocean: Baja California, Mexico to Peru; Atlantic Ocean: Gulf of Mexico, Caribbean Sea and Brazil, in the states of Paraíba (Ananias, 2017) and São Paulo (Zibrowius, 1970; Morgado, 1980; Souza, 1989; Rocha, 1993, 1995). In this study, members of this species were found among material from the states of Alagoas, Rio de Janeiro and Santa Catarina, extending the distribution of these animals from off the northeastern through the southern Brazilian coast, until Santa Catarina.

\section{Spirobranchus tetraceros (Schmarda, 1861) (Figs. 7, 8, 9)}

Pomatoceros tetraceros Schmarda, 1861. Spirobranchus tricornis. Straughan (1967). Spirobranchus tetraceros. ten Hove (1970). Spirobranchus dendropoma. ten Hove (1970). Spirobranchus giganteus. Dew (1959); Skinner et al. (2012). Complex-Spirobranchus tetraceros. ten Hove (1994).

Examined material: 28 specimens. Rio de Janeiro state, Ilha Grande Bay, Angra dos Reis Municipality: Cataguases Island: $23^{\circ} 01^{\prime} 28.57^{\prime \prime} \mathrm{S}, 44^{\circ} 17^{\prime} 06.52^{\prime \prime} \mathrm{W}$, intertidal, MNRJP-002787 (2 specimens). Paraty Municipality: Catimbau Island: $23^{\circ} 11^{\prime} 42.41^{\prime \prime} \mathrm{S}, \quad 44^{\circ} 37^{\prime} 33.19^{\prime \prime} \mathrm{W}$, UERJ6284 (1 specimen). Mangaratiba Municipality: Ibicuí Beach: $22^{\circ} 57^{\prime} 45.30^{\prime \prime} \mathrm{S}, 4^{\circ} 01^{\prime} 28.50^{\prime \prime} \mathrm{W}$, MNRJP-002788 (10 specimens). Itaguaí Municipality: Coroa Grande Beach: $22^{\circ} 54^{\prime} 24.34^{\prime \prime} \mathrm{S}, 43^{\circ} 52^{\prime} 00.26^{\prime \prime} \mathrm{W}$, MNRJP-002789 (15 specimens)

Diagnosis (after Kupriyanova et al., 2015): Opercular plate mostly flat, sometimes conical; basally carrying 1 mid-ventral and 2 dorso-lateral spines ("tricornis" condition); alternatively, some specimens with mid-ventral spine as two fully separated spines, which, considering pair latero-dorsal spines, makes 4 primary spines ("tetraceros" condition). All spines split at least once, frequently twice or three times, resulting in 6-14 spine tips. Completely conical opercula, with only 3 rudimentary spines or spines completely absent. Peduncular wings with finger-like processes distally (rallely without).

\section{Description}

Tube: Opaque, white or pinkish. Triangular in cross-section, lumen circular. One serrated longitudinal keel throughout, extending over the opening as pointed tip (Fig. 7A). Tubes solitary.

Radiolar Crown: Live specimens alternating bands of white iridescent, yellow, brown, pink, and orange coloration at crown (Fig. 7B). Coloration faded after preservation, only darker shades remaining. Crown as two spiraled lobes with 1 whorl, each with up to 27 radioles, basally joined by inter-radiolar membrane for one third of their length; inter-radiolar membrane bearing triangular distal processes, with fringed edges (Fig. 7C), usually white iridescent (Fig. $7 \mathrm{H}$ ). Radioles rectangular in cross-section, inner side with two rows of filiform pinnules of even length through radioles, with naked tips. Naked tips filiform and about as long as pinnules. Dorsal radioles longer than ventral ones. Scattered simple ocelli, in irregular rows through radioles. 
Mouth Parts: Two thin, smooth lips. Dorsal lips rectangular, forming pair of lateral cylindrical grooved palps, basally flat, about half as long as dorsal radioles (Fig. 7l). Ventral lip rectangular, about as long as dorsal lips, as internal lap through bases of radiolar lobes.

Peduncle: Smooth, triangular in cross-section, inserted slightly left to dorsal mid-line. Pair of smooth lateral wings distally, bilobed, dorsal lobe circular, lateral lobe triangular, both with fringed edges (Fig. 7F). Constriction between peduncle and opercular base absent. Darkbrown, alternating white iridescent bands often present, with scattered pigmentation, as in crown. Coloration pattern usually extending into lateral wings.

Operculum: Continuous with the peduncle. Opercular ampulla flat, circular to oval in top view, calcareous endplate usually white or beige. Endplate varying from a ridged conical (Fig. 7D) structure to a flat plate with three main spines (Fig. 7E), two dorso-lateral and one medio-ventral, wich may split at base, resulting in four main concentric spines (Figs. 7F, 7G). Spines covered by spaced smaller spines. Multiple branching in each spine resulting in many degrees of development of spines observed in a population. Talon absent.

Collar and Thoracic Membranes: Three-lobed collar. Dorso-lateral lobes longer, circular, with entire edges, continuous with thoracic membranes, forming a ventral apron covering 1 abdominal chaetiger (Fig. $7 \mathrm{H}$ ). Midventral lobe rectangular with pointed median tip, shorter than dorso-lateral lobes, often folded medially, inserted between crown lobes. Tonguelets present between lateral and ventral lobes; bilobed, inner lobes half-length of outer lobes, both circular, with smooth rim (Figs. 7H, 9G, 9H). Collar lobes commonly same color as crown base, extending through thorax. Internally, collar and tonguelets may be covered in white iridescent pigmentation.

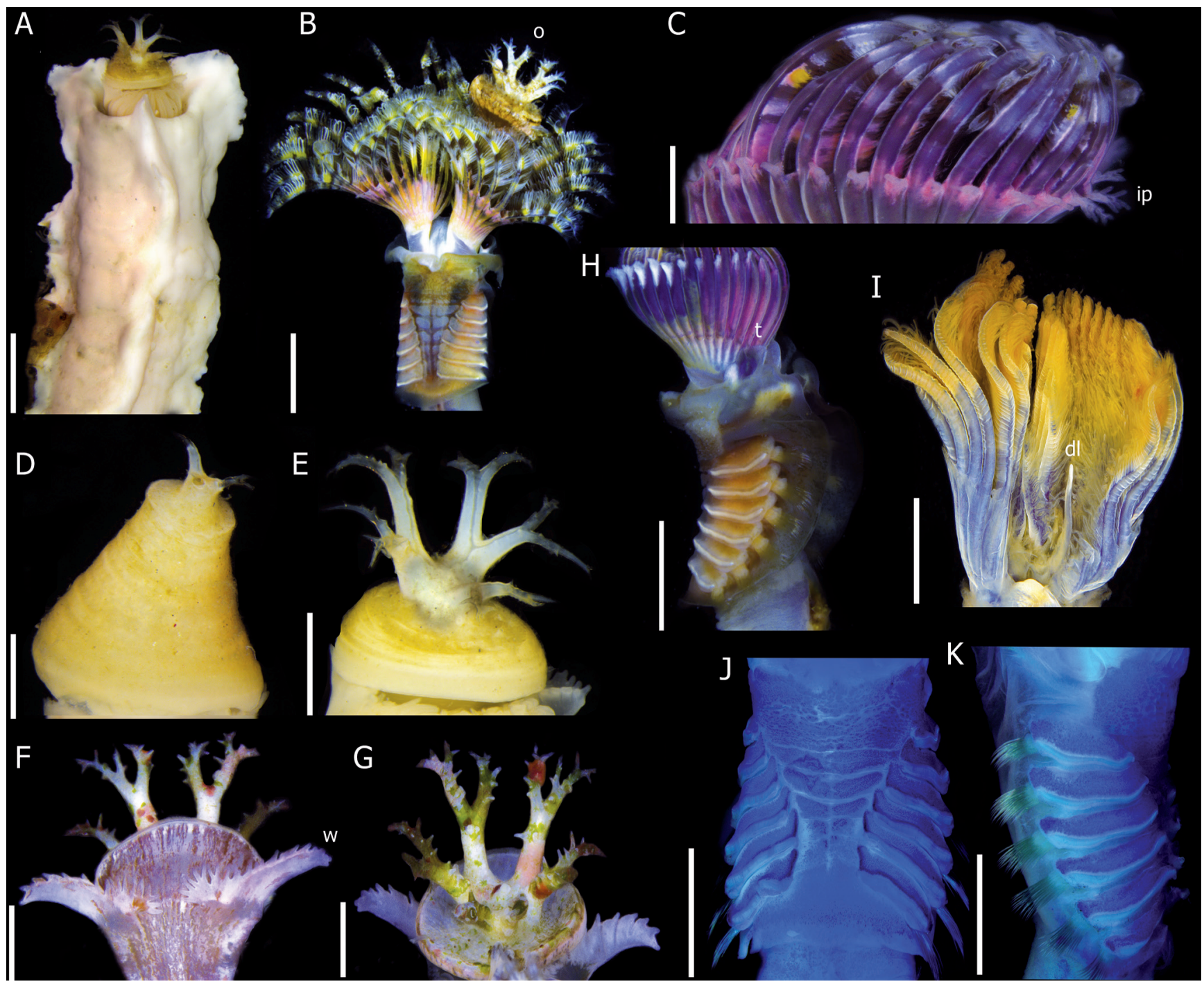

Figure 7. Spirobranchus tetraceros. (A, D-E, J) MNRJP-002788; (B-C, F-I) MNRJP-002789. (A) anterior end of tube with exposed operculum, (B) anterior end through anterior abdomen of specimen with 'tetraceros' condition, ventral view, $(C)$ radioles and interradiolar membrane, (D) conical 'tricornis' operculum, (E) 'tricornis' opercular condition, $(\mathrm{F}, \mathrm{G})$ peduncular wings, in a 'tetraceros' operculum, $(\mathrm{F})$ dorsal view, $(\mathrm{G})$ ventral view, $(\mathrm{H})$ anterior end, from base of crown through anterior abdomen, lateral view, (I) inner side of crown and dorsal lip, (J) thorax (except collar), ventral view, stained with methylene blue, (K) same, lateral view. Scale bars = $1 \mathrm{~mm}(\mathrm{~A}, \mathrm{~B}), 0,4 \mathrm{~mm}(\mathrm{D}, \mathrm{E}), 0,5 \mathrm{~mm}(\mathrm{~F}, \mathrm{G}, \mathrm{H}, \mathrm{I}, \mathrm{J}, \mathrm{K}), 0,2 \mathrm{~mm}(\mathrm{C}) . \mathrm{d}=$ dorsal lip; ip = inter-radiolar processes; $0=$ operculum; $\mathrm{t}=$ tonguelets; $\mathrm{w}=$ wing. 
Thorax: Seven chaetigers. Collar chaetae as Spirobranchus-type and limbate chaetae, disposed in one fascicle (Fig. 8L). After collar, notopodial lobes round, emerging between thoracic membranes and neuropodia. Thoracic chetae limbate, in three fascicles of differ- ent lengths per notopodium (Figs. 8M, 8N). Neuropodial lobes rectangular, all bearing tori curved downwards of even length through thorax. Thoracic uncini saw-shaped, with 13-16 curved teeth, and gouged anterior peg (Fig. 80). Parapodial lobes approaching each other pos-

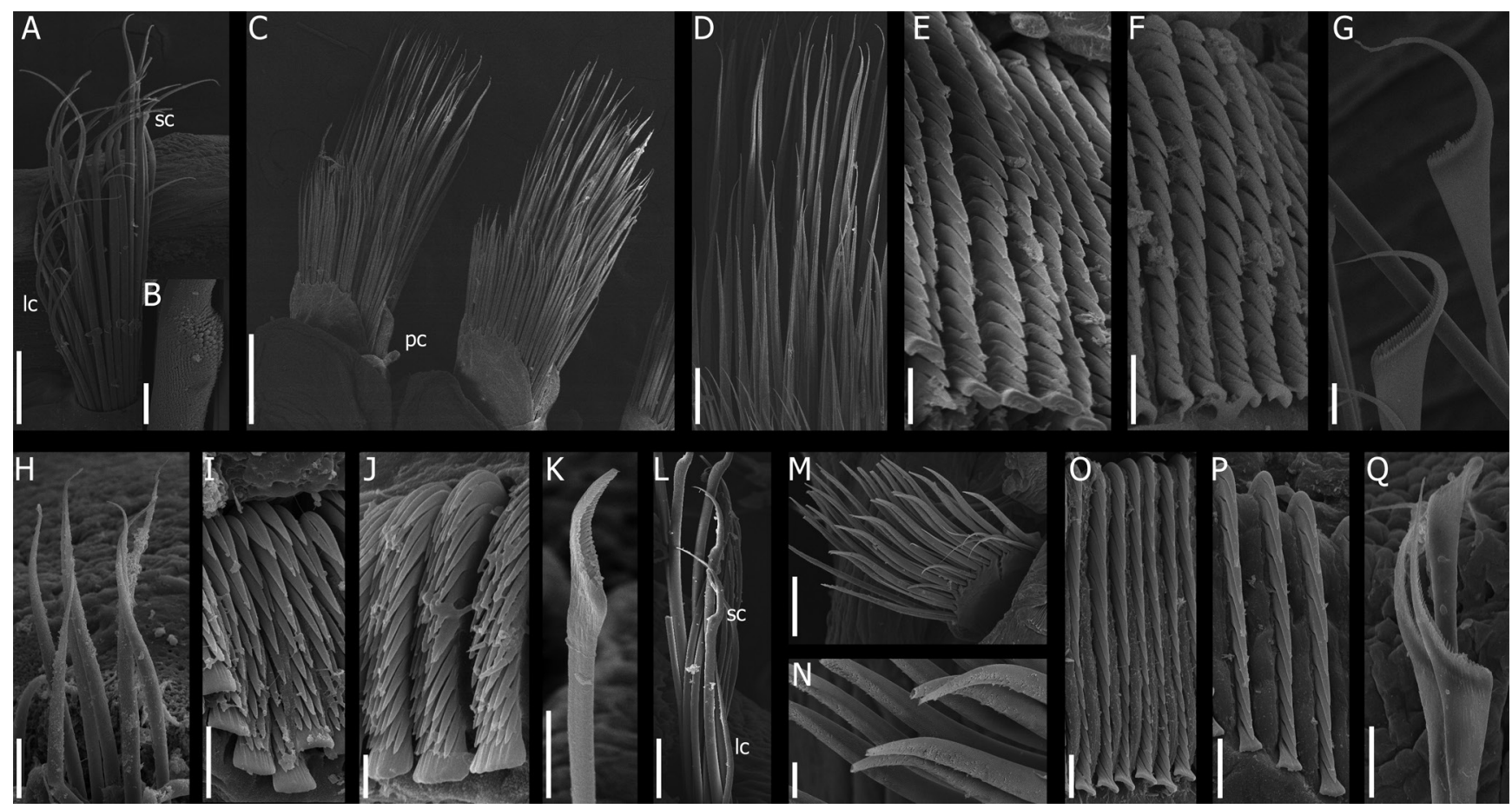

Figure 8. SEM images of chaetae from species of Spirobranchus reported in Brazil. (A-G) S. giganteus (MNRJP-002779): (A) collar chaetae, (B) detail of shaft of Spirobranchus-type chaeta, (C) thoracic notopodia, (D) limbate thoracic notochaetae, (E) thoracic uncini, (F) abdominal uncini, (G) abdominal trumpet-shaped neurochaetae; (H-K) S. minutus (MNRJP-002785): (H) limbate thoracic notochaetae, (I) thoracic uncini, (J) abdominal uncini, (K) abdominal trumpet-shaped neurochaetae (lateral projection broken); (L-Q) S. tetraceros (MNRJP-002789): (L) collar chaetae, (M) thoracic notopodium, (N) detail of limbate thoracic notochaetae, (0) thoracic uncini, $(P)$ abdominal uncini, $(Q)$ abdominal trumpet-shaped neurochaetae. Scale bars $=500 \mu \mathrm{m}(\mathrm{C}), 200 \mu \mathrm{m}(\mathrm{A}, \mathrm{M}), 100 \mu \mathrm{m}(\mathrm{D}, \mathrm{L}), 20 \mu \mathrm{m}(\mathrm{N}, \mathrm{Q})$, $10 \mu \mathrm{m}(\mathrm{B}, \mathrm{E}, \mathrm{F}, \mathrm{G}, \mathrm{H}, \mathrm{K}, \mathrm{O}, \mathrm{P}), 5 \mu \mathrm{m}(\mathrm{I}), 2 \mu \mathrm{m}(\mathrm{J}) . \mathrm{IC}=$ limbate chaeta; $\mathrm{pC}=$ parapodial cirrus; $\mathrm{SC}=$ Spirobranchus-type chaeta.
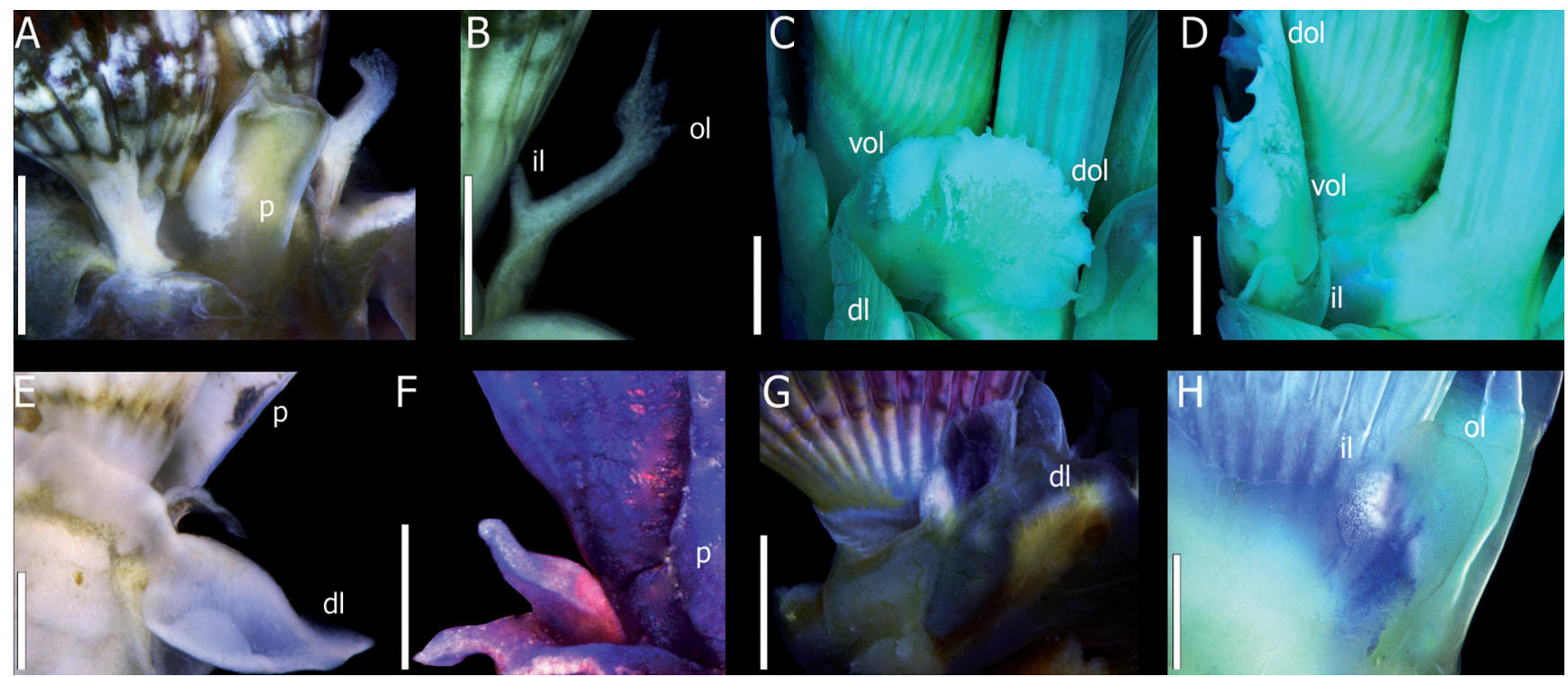

Figure 9. Tonguelets among members of Spirobranchus spp. (A, B) S. lirianeae sp. nov.: (A) Paratype (MNRJP-002775) peduncle and dorso-lateral collar lobes dissected, (B) Paratype (MNRJP-002777) detail of the bilobed tonguelet; (C, D) S. giganteus (MNRJP-002779): (C) dorsal view, (D) dorsal view with dorsal outer lobe folded backwards, exposing inner lobe; (E, F) S. minutus (MNRJP-002783): (E) lateral view, (F) detail of tonguelet, dorsal view, stained with Shirlastain, with dorso-lateral collar lobe dissected; (G, H) S. tetraceros (MNRJP-002789): (G) lateral view, (H) detail of lateral view stained with methylene blue, outer lobe over inner lobe. Scale bars $=300 \mu \mathrm{m}(\mathrm{G}), 200 \mu \mathrm{m}(\mathrm{A}, \mathrm{C}, \mathrm{D}, \mathrm{H}), 150 \mu \mathrm{m}(\mathrm{B}), 100 \mu \mathrm{m}(\mathrm{E}), 50 \mu \mathrm{m}$ (F). dol = dorsal outer tonguelet lobe; dl = dorsolateral colar lobe; il = inner tonguelet lobe; $\mathrm{ol}=$ outer tonguelet lobe; $\mathrm{p}=$ peduncle; $\mathrm{vol}=$ ventral outer tonguelet lobe. 
teriorly, forming ventral triangular depression. Glandular clusters covering ventral portion of mid-ventral collar lobe, as heart-shaped pattern, together with triangular depression (Figs. 7J, 7K), also covering all thoracic neuropodia, except for origin of tori. Five pairs of ventral glandular shields, first two pairs rectangular, fused to each other mid-ventrally, other three pairs not fused and posteriorly becoming squared (Figs. 7J, 7K).

Abdomen: Largest analyzed specimen with 97 abdominal segments. Abdomen in entire animals usually four times longer than thorax. Notopodial uncini smaller than thoracic ones, saw-shaped, with 10-11 teeth and gouged anterior peg (Fig. 8P). Neuropodial chaetae true trumpet-shaped, abruptly bent, with 2 distal rows of denticles separated by groove and lateral serrated filiform projection (Fig. 8Q). Ventral pads square-shaped anteriorly and rectangular posteriorly. Glandular clusters present over tori, and along the rim of fecal sulcus, concentrated at posterior abdomen. Pygidium bilobed, with terminal anus.

Remarks: The occurrence of S. tetraceros in the Atlantic has been deemed indicative of a species complex (Smith, 1985; Fiege \& ten Hove, 1999; ten Hove \& Kupriyanova, 2009). This species was first described in Australia (Schmarda, 1861) and its members are similar to those of the Caribbean S. dendropoma Mörch, 1863. Spirobranchus dendropoma has been treated as a synonym of $S$. tetraceros (e.g., ten Hove, 1970), but that status is questionable, given the improbability of an Indo-Pacific species occurring in the Caribbean (Bastida-Zavala \& Salazar-Vallejo, 2000; Bastida-Zavala, 2009; Perry et al., 2018). However, morphologically, members of both these species differ in terms of the processes present at the distal edge of the interradiolar membrane, which are smooth among specimens of S. dendropoma, and positioned at the base of the radioles (Benedict, 1887), whereas they are fringed in animals belonging to $S$. tetraceros, and at the distal end of the interradiolar membrane (Bastida-Zavala \& SalazarVallejo, 2000). Perry et al. (2018) alert that S. tetraceros is an extensively distributed complex of species, though that do not exclude the likelihood of either of these species being introduced distant to the type-locality. The specimens we analyzed are compatible with descriptions of $S$. tetraceros, and the occurrence of this exotic species in Brazil was recently noticed (Rodrigues et al., 2020), thus we retain the identification of the mentioned previous authors.

Members of S. tetraceros share with those of S. giganteus the tube with a pointed longitudinal keel, operculum ornamented by thorns, and special collar chaetae. However, the tube of members of the former species may present serrations on the keel, which are absent in S. giganteus. The radiolar lobes of individuals of S. giganteus form multi-whorled spirals, whereas they form a single circle in members of S. tetraceros. The opercular thorns of specimens of $S$. tetraceros are more numerous, up to four, concentric and branched, with multiple tips, while in animals of S. giganteus there are two dorso-later- al and a possible third mid-ventral thorn, shorter, in a triangular arrangement with other thorns on the opercular endplate. The tonguelets of members of $S$. tetraceros are bilobed with smooth edges, whereas specimens of S. giganteus present trilobed tonguelets, with superior outer lobe larger and with wavy edge. The peduncular wings and interradiolar processes of animals of S. tetraceros are fringed, while in members of $S$. giganteus the wings are smooth, and the processes are absent. Members of $S$. tetraceros have 5 pairs of glandular shields in thoracic triangular depression, while those of S. giganteus have a single shield.

Spirobranchus tetraceros differs from S. minutus because members of $S$. minutus have a triple-keeled tube, with alveoli, lack both opercular ornamentation and radiolar ocelli, and the collar chaetae, if present, are limbate, while in members of $S$. tetraceros the tube has a single keel, the operculum is ornamented, photoreceptor structures are present and the collar chaetae are limbate and special Spirobranchus-type.

Members of S. tetraceros share with S. lirianeae sp. nov. the shape of the tube, with single pointed longitudinal keel, but they differ from those animals in having opercular ornamentation, simple radiolar ocelli, fringed interradiolar processes, and collar chaetae, while members of S. lirianeae sp. nov. have funnel-shaped operculum, lacking thorns and spines, and also have paired compound ocellar clusters in the radioles and interradiolar processes, whereas collar chaetae are absent. The fringed peduncle wings and the presence of interradiolar processes distinguish this species from any other recorded in Brazil to date.

Type-locality: New South Wales, Australia (Pacific Ocean).

Habitat: Intertidal: rocky shores, beneath rocks; subtidal: rocky shores, under rocks, at fouling communities on piers. Often found associated to Tubastraea spp. (Cnidaria: Anthozoa: Scleractinia). Also found on artificial substrata, such as concrete blocks and plastic incrustation plates (Rodrigues et al., 2020).

Distribution: Indian Ocean: Australia, Phillipines, off China (Sun et al., 2012), Red Sea (Perry et al., 2017), Aqaba Gulf, eastern coast of Africa and Madagascar (Read, 2019); Pacific Ocean: Australia; Atlantic Ocean: Mediterranean Sea, Greek, Caribbean Sea (ten Hove, 1970), Gulf of México, Colombia (Read, 2019) and southeastern Brazil, at Rio de Janeiro state (Skinner et al., 2012; Rodrigues et al., 2020).

\section{Key for the species of Spirobranchus recorded in Brazil}

1. Radiolar lobes forming 2-8 whorls in spiral ......................... S. giganteus

1. Radiolar lobes in 1 whorl or semicircular ................................................. 2

2. Spirobranchus-type chaetae present ....................................... tetraceros

2. Collar chaetae all limbate or absent.................................................... 3 
3. Operculum with flat or convex, bilobed endplate; ocelli or ocelar clusters absent on radioles; tube with 3 keels and alveoli S. minutus

3'. Operculum with concave, funnel-shape endplate; paired ocelar clusters present on radioles; tube with 1 pointed keel and transversal ridges... S. lirianeae sp. nov.

\section{DISCUSSION}

Spirobranchus, as well as other serpulids, can be transported through human activity to regions beyond their natural distribution, often resulting in misidentifications. Çinar (2013) reported four species of Spirobranchus as potential invasives far from their type localities. Simon et al. (2019) further highlighted the confusion surrounding species complexes and cryptic species. Molecular studies are not unusual attempts to clarify such conflicts (e.g., Sun et al., 2016, 2017; Perry et al., 2018), but morphological analyses need to progress in concert with molecular techniques to define new structural characters for specimen identification. Currently, visual identification focuses on the operculum and tube. While very wide distributions of marine organisms deserve to be questioned, serpulids such as Hydroides elegans (Haswell, 1883) have already demonstrated the potential for long-distance dispersal and successful introduction, in this case from Australia to much of the world, including Brazil (Hutchings \& Kupriyanova, 2018), apparently like $S$. tetraceros, demonstrating the importance of refining the taxonomy of the group by searching for new characters and establishing accurate morphological descriptions.

Here, we highlight important characters for distinguishing species of Spirobranchus (Table 1), which will prove informative for future phylogenetic analyses. We noted that tonguelet shape varied considerably among the four species reported from Brazil, from simple and leaf-shaped, as among members of S. minutus, to multilobed structures, with rippled fringed edges, such as exhibited by individuals of S. giganteus and S. lirianeae sp. nov. (Fig. 9). Typically, these structures are not described. For instance, Pillai (2009) conducted a review of numerous species of Spirobranchus, but never mentioned their tonguelets. If mentioned, it is only a passing reference to the presence/absence of tonguelets (ten Hove \& Kupriyanova, 2009; Kupriyanova et al., 2015). So, in general, the morphology of these structures remains underestimated and their potential taxonomic utility is underappreciated (Perry et al., 2018; Simon et al., 2019).

We also observed considerable variation in oral palp morphology. Although difficult to visualize, given their location inside the crown and association with the dorsal lips, we noted unique size variation relative to the size of the crown, in members of each species reported herein.

Similarly, glandular distribution is little explored in serpulids, despite this characteristic being important for delineating species of Sabellidae (e.g., Capa \& Murray, 2015). In this respect, the work of Wong et al. (2014) is important, since it provides an illustrated glossary of Spirobranchus spp. stained with methylene blue, which

\begin{tabular}{|c|c|c|c|c|c|c|}
\hline 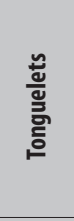 & 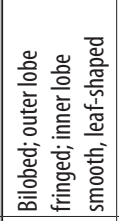 & 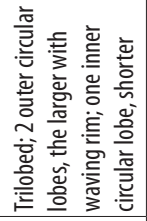 & 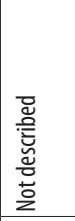 & 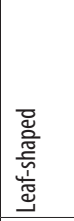 & 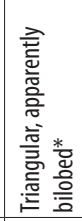 & 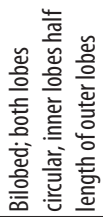 \\
\hline 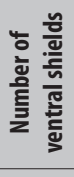 & 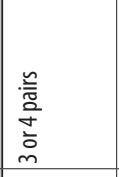 & $\begin{array}{l}\frac{\overline{0}}{0} \\
\frac{0}{0} \\
\frac{0}{\bar{m}} \\
\end{array}$ & 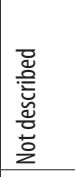 & 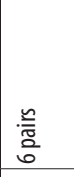 & 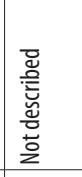 & 产 \\
\hline 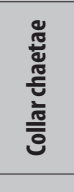 & 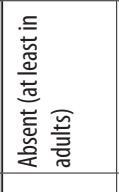 & 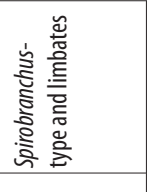 & 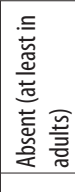 & 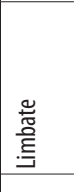 & 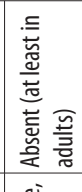 & 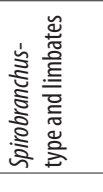 \\
\hline 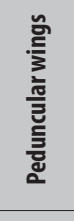 & $\begin{array}{l}\text { 訔 } \\
\text { 言 } \\
\text { 毫 } \\
\text { 言 } \\
\text { 总 } \\
\end{array}$ & 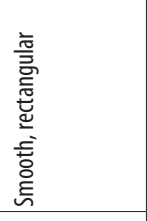 & 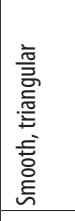 & \begin{tabular}{|l} 
흘 \\
言 \\
高 \\
吾 \\
言 \\
总 \\
\end{tabular} & 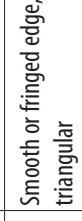 & 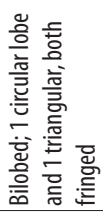 \\
\hline 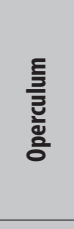 & 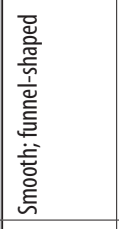 & 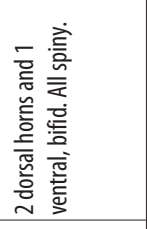 & 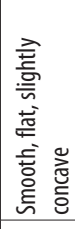 & 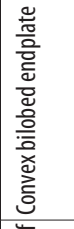 & 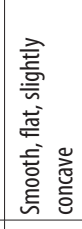 & 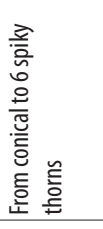 \\
\hline 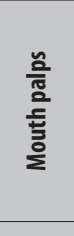 & 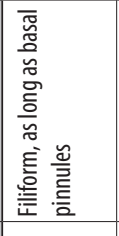 & 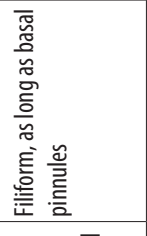 & 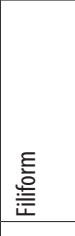 & 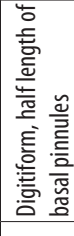 & 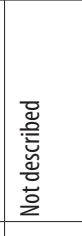 & 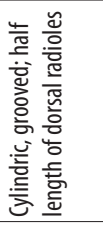 \\
\hline 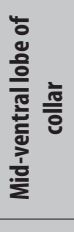 & 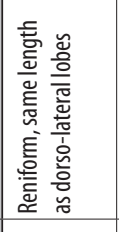 & 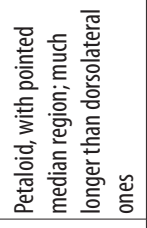 & 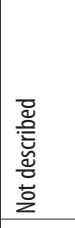 & 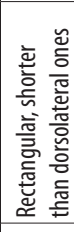 & 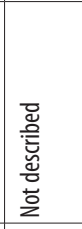 & 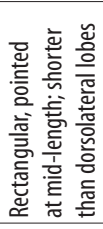 \\
\hline 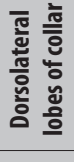 & 意 & 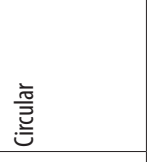 & 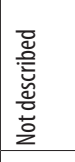 & 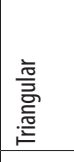 & 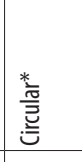 & 镑 \\
\hline 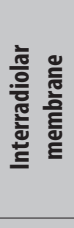 & 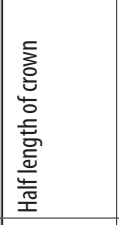 & 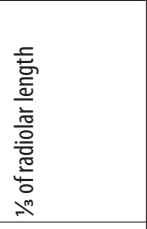 & 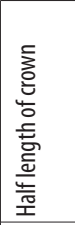 & 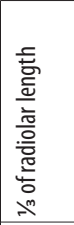 & 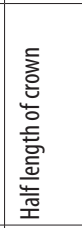 & 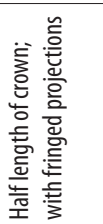 \\
\hline 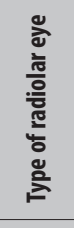 & 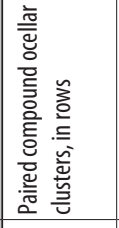 & 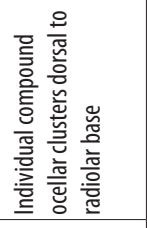 & 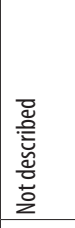 & $\begin{array}{l}\text { 志 } \\
\text { 妾 }\end{array}$ & 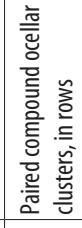 & 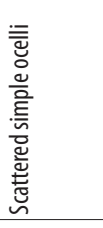 \\
\hline 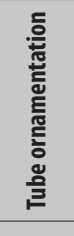 & 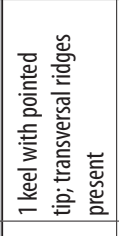 & 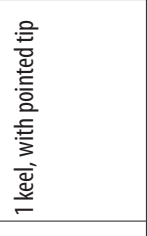 & 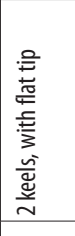 & 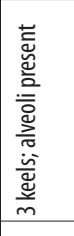 & 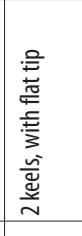 & 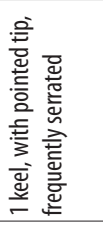 \\
\hline 氶 & 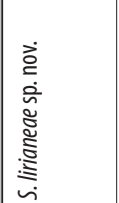 & 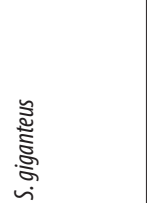 & 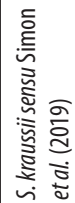 & 总 & 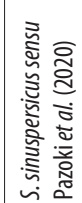 & 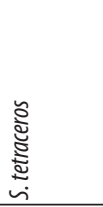 \\
\hline
\end{tabular}


highlights the ventral shields, though the focus of that work was to present these structures rather than compare them taxonomically.

The species thus far recorded from the Brazilian coast all present different glandular patterns in the ventral region of the collar, and the number of ventral glandular shields on thoracic triangular depression varies from a single shield, as among members of S. giganteus, to up to six pairs of shields, as among animals of $S$. minutus, with no overlapping among the individuals of the species accounted in the present work. The uncini of the species we assessed also differ (Fig. 8). Members of S. minutus are notable in having rasp-shaped uncini, whereas the uncini of members of the other species of this genus occurring off Brazil are all saw-shaped. However, the number of teeth in these uncini differs, higher among members of S. giganteus, lower in individuals of S. lirianeae sp. nov., and intermediate in specimens of $S$. tetraceros.

The Serpulidae are undoubtedly a family presenting intraspecific variations that challenge species delimitation, especially when species introductions to sites far from type localities are considered. However, many anatomical characters can be used for morphological taxonomy, such as those related to the operculum and tube, and further detailed research into novel characters and defining character ranges could greatly enable species identification.

\section{ACKNOWLEDGMENTS}

We are thankful to Harry ten Hove, José Rolando Bastida-Zavala and Elena Kupriyanova for discussions about identities of Spirobranchus in Atlantic Ocean. We also wish to thank Fundação Oswaldo Cruz for providing access to scanning electron microscopy. We are also thankful to Hilda Helena Sovierzoski, from Universidade Federal de Alagoas, Alexandra Rizzo, from Universidade Estadual do Rio de Janeiro, and Joana Zanol, from the National Museum of Universidade Federal do Rio de Janeiro, for lending collection's specimens of Spirobranchus from several localities off the Brazilian coast. Finally, we are thankful to Coordenação de Aperfeiçoamemto de Pessoal de Nível Superior (CAPES), for supporting the Project, which led to this paper. SISBIO authorization number 67315-1.

\section{REFERENCES}

Amaral, A.C.Z.; Nallin, S.A.H.; Steiner, T.M.; Forroni, T.O. \& Gomes-Filho, D. 2013. Catálogo das espécies de Annelida Polychaeta do Brasil. Campinas, Unicamp, 83p. http://www.ib.unicamp.br/museu zoologia/files/ lab museu zoologia/Cat\%C3\%A1logo Polychaeta Brasil Amaral et al 2013 1a.pdf.

Ananias, C.D.N. 2017. Diversidade de Serpulidae (Annelida, Polychaeta) entre as regiões Sul e Nordeste do Brasil. (Masters Dissertation). Universidade de São Paulo, Brazil. DOI

Baird, W. 1864. Description of several new species and varieties of Tubicolous Annelides = Tribe Limivora of Grube, in the collection of the British
Museum. The Journal of the Linnean Society of London. Zoology, 8: Part 1 p. 10-16, plate I, figs. 2-4; Part 2, p. 16-22, plate II.

Bastida-Zavala, J.R. 2008. Serpulids (Annelida: Polychaeta) from the Eastern Pacific, including a brief mention of Hawaiian serpulids. Zootaxa, 1722: 1-61.

Bastida-Zavala, J.R. 2009. Serpulidae Rafinesque, 1815. In: De León-González, J.A.; Bastida-Zavala, J.R.; Carrera-Parra, L.F.; García-Garza, M.E.; PeñaRivera, A.; Salazar-Vallejo, S.I. \& Solís Weiss, V. Poliquetos (Annelida: Polychaeta) de México y América Tropical. Universidad Autónoma de Nuevo León, Monterrey, Tome III.

Bastida-Zavala, J.R. \& Salazar-Vallejo, S.I. 2000. Serpúlidos (Polychaeta:Serpulidae) del Caribe noroccidental con claves para la región del Gran Caribe: Salmacina, Ficopomatus, Pomatoceros, Pomatostegus, Protula, Pseudovermilia, Spirobranchus y Vermiliopsis. Revista de Biología Tropical, 48(4): 807-840.

Bastida-Zavala, J.R.; McCann, L.D.; Keppel, E. \& Ruiz, G.M. 2017. The fouling serpulids (Polychaeta: Serpulidae) from United States coastal waters: An overview. European Journal of Taxonomy, 344: 1-76.

Benedict, J.E. 1887. Descriptions of ten species and one new genus of the Annelids from the dredgings of the U.S. Fish Commission Steamer Albatross. Proceedings of the United States National Museum, 9: 547-553.

Blainville, H.M.D. 1818. Mémoire sur la classe des Sétipodes, partie des Vers à sang rouge de M. Cuvier, et des Annélides de M. de Lamarck. Bulletin des Sciences, par la Société Philomatique de Paris, (1817-1819): 78-85.

Blainville, H.M.D. 1828. Mollusques, Vers et Zoophytes. In: F.G. Levrault: Dictionnaire des Sciences naturelles, dans lequel on traite methodiquement des differens etres de la nature, consideres soit en eux-memes. d'apres l'etat actuel de nos connais sciences, soit relativement a l'utilite qu'en peuvent retirer la medicine, l'agriculture, le commerce et les arts. Suive d'une biographie des plus celebres naturalists, vol. 57, Strasbourg, Paris. 430p.

Bok, M.J.; Porter, M.L.; ten Hove, H.A.; Smith, R. \& Nilsson, D. 2017. Radiolar eyes of serpulid worms (Annelida, Serpulidae): Structures, function, and phototransduction. Biological Bulletin, 233(1): 39-57.

Capa, M. \& Murray, A. 2015. A taxonomic guide to the fanworms (Sabellidae, Annelida) of Lizard Island, Great Barrier Reef, Australia, including new species and new records. Zootaxa, 4019(1): 98-167.

Çinar, M.E. 2013. Alien polychaete species worldwide: Current status and their impacts. Journal of the Marine Biological Association of the United Kingdom, 93(5): 1257-1278.

Correia, M.D. \& Sovierzoski, H.H. 2009. Ecossistemas Costeiros de Alagoas Brasil. Rio de Janeiro, Technical Books.

Day, J.H. 1973. New Polychaeta from Beaufort, with a Key to All Species Recorded from North Carolina. NOAA Techinical Report, Nacional Marine Fisheries Service, CIRC-375: 1-140.

Day, J.R. 1955. The Polychaeta of South Africa. 3. Sedentary species from Cape shores and estuaries. Zoological Journal of the Linnean Society, 42: 407-452.

Dew, B. 1959. Serpulidae (Polychaeta) from Australia. Records of the Australian Museum, 25(2): 19-56.

Fiege, D. \& ten Hove, H.A. 1999. Redescription of Spirobranchus gaymardi (Quatrefages, 1866) (Polychaeta: Serpulidae) from the Indo-Pacific with remarks on the Spirobranchus giganteus complex. Zoological Journal of the Linnean Society, 126: 355-364.

Gray, J.E. 1843. Fauna of New Zealand. In: Dieffenbach, E. Travels in New Zealand. London. vol. 2.

Haswell, W.A. 1883. On some new Australian tubicolous annelids. Proceedings of the Linnean Society of New South Wales, 7(4): 633-638.

Humason, G.L. 1979. Animal tissue techniques. 4.ed. San Francisco, W.H. Freeman and $\mathrm{C} 0$.

Hutchings, P.\& Kupriyanova, E. 2018. Cosmopolitan polychaetes - fact or fiction? Personal and historical perspectives. Invertebrate Systematics, 32: 1-9. 
Jones, M.L. 1962. On some polychaetous annelids from Jamaica, the West Indies. Bulletim of the American Museum of Natural History, 124(5): 169-212.

Kupriyanova, E.K.; Sun, Y.; ten Hove, H.A.; Wong, E. \& Rouse, G.W. 2015. Serpulidae (Annelida) of Lizard Island, Great Barrier Reef, Australia. Zootaxa, 4019(1): 275-353.

Linnaeus, C. 1758. Systema Naturae per regna tria naturae, secundum classes, ordines, genera, species, cum characteribus, differentiis, synonymis, locis. Editio decima, reformata. Holmiae, Laurentius Salvius. 824p.

Miranda, V.R. \& Brasil, A.C.S. 2014. Two new species and a new record of scale-worms (Polychaeta) from Southwest Atlantic deep-sea coral mounds. Zootaxa, 3856(2): 211-226.

Moore, J.P. 1923. The polychaetous annelids dredged by the U.S.S. "Albatross" off the coast of southern California in 1904. IV. Spionidae to Sabellariidae. Proceedings of the Academy of Natural Sciences of Philadelphia, 75: 179-259.

Mörch, 0.A.L. 1863. Revisio critica Serpulidarum. Et Bidrag til Rørormenes Naturhistorie. Naturhistorisk Tidsskrift, 3(1): 347-470.

Morgado, E.H. 1980. A Endofauna de Schizoporella unicornis (Johnston, 1847) (Bryozoa) no Litoral Norte do Estado de São Paulo. (Doctoral Thesis). Universidade Estadual de Campinas, Brazil.

Nygren, A. 2014. Cryptic polychaete diversity: A review. Zoologica Scripta, 43(2): 172-183.

Pallas, P.S. 1766. Miscellanea Zoologica, animalium species describuntur et observationibus iconibusque illustrantur. Hagae Comitum, Petrum van cleef. 224p. D0I

Pazoki, S.; Rahimian, H.; Struck, T.H.; Katouzian, A.R. \& Kupriyanova, E.K. 2020. A new species of the Spirobranchus kraussii-complex (Annelida, Serpulidae) from the Persian Gulf and Gulf of Oman. Zootaxa, 4748(3): 401-430. DOI

Perry, 0.; Bronstein, 0.; Simon-Blecher, N.; Atkins, A.; Kupriyanova, E.; ten Hove, H.A.; Levy, 0. \& Fine, M. 2018. On the genus Spirobranchus (Annelida, Serpulidae) from the northern Red Sea, and a description of a new species. Invertebrate Systematics, 32(3): 605-626.

Perry, 0.; Sapir, Y.; Perry, G.; ten Hove, H.A.; Fine, M. 2017. Substrate selection of Christmas tree worms (Spirobranchus spp.) in the Gulf of Eilat, Red Sea. Journal of the Marine Biological Association of the United Kingdom, 98(4): 791-799. DOI

Philippi, A. 1844. Einige Bemerkungen über die Gattung Serpula, nebst Aufzählung der von mir im Mittelmeer mit dem Thier beobachteten Arten. Archiv für Naturgeschichte, Berlin, 10(1): 186-198.

Pillai, T.G. 2009. Descriptions of New Serpulid Polychaetes from the Kimberleys of Australia and Discussion of Australian and Indo-West Pacific Species of Spirobranchus and Superficially Similar Taxa. Records of the Australian Museum, 61: 93-199.

Pixell, H.L.M. 1913. Polychaeta of the Indian Ocean, together with some species from the Cape Verde Islands. The Serpulidae, with a classification of the genera Hydroides an Eupomatus. Transactions of the Linnean Society of London (Series 2), 16: 69-92.

Read, G. 2019. Spirobranchus tetraceros (Schmarda, 1861). World Polychaeta database. Available at: http://www.marinespecies.org/aphia. php? $\mathrm{p}=$ taxdetails\&id $=131055$. Access in: 30/10/2019.

Read, G. 2020. Spirobranchus giganteus (Pallas, 1776). World Polychaeta database. Available at: http://www.marinespecies.org/aphia. php? $p=$ taxdetails\&id=209944. Access in: 03/01/2020.

Rioja, E. 1941. Estudios Anelidologicos. III. Datos para el conocimiento de la fauna de poliquetos de las costas del pacifico de Mexico. Anales del Instituto de Biologia, Mexico, 12(2): 669-746.

Rocha, R.M. 1993. Comunidade Incrustante em Substrato Duro não Estabilizado na Zona Entremarés (São Sebastião-SP). (Doctoral Thesis). Universidade Estadual de Campinas, Brazil.
Rocha, R.M. 1995. Abundance and distribution of sessile invertebrates under intertidal boulders (São Paulo, Brasil). Boletim do Instituto Oceanográfico, São Paulo, 43(1): 71-88.

Rodrigues, A.R.; Skinner, L.F. \& Brasil, A.C.S. 2020. Do morphological similarities and human-induced dispersal explain the non-native occurrence of Serpulidae (Annelida) in Southwest atlantic? Taxonomic detailing is the key. Papeis Avulsos de Zoologia, São Paulo, 60(5): 1-15, e20206005.

Rullier, F. \& Amoureux, L. 1979. Campagne de la Calypso au large des cotes Atlantiques del'Amerique du Sud (1961-1962). I.33. Annélides Polychétes. Annales de I'Institut Océanographique, Paris, 55(Suppl.): 145-206.

Santa-Isabel, L.M.; Leão, Z.M.A.N. \& Peso-Aguiar, M.C. 2000. Polychaetes from the Guarajuba coral reefs, Bahia, Brazil. Bulletim of Marine Science, 67(1): 645-653.

Schmarda, L.K. 1861. Neue wirbellose Thiere beobachtet und gesammelt auf einer Reise um die Erde 1853 bis 1857. Erster Band (zweite Hälfte) Turbellarian, Rotatorien und Anneliden. Leipzig, Wilhelm Engelmann.

Simon, C.; Niekerk, H.H.; Burghardt, I.; ten Hove, H.A. \& Kupriyanova, E.K. 2019. Not out of Africa: Spirobranchus kraussii (Baird, 1865) is not a global fouling and invasive serpulid of Indo-Pacific origin. Aquatic Invasions, 14(2): 221-249.

Skinner, L.F.; Tenório, A.A.; Penha, F.L. \& Soares, D.C. 2012. First record of Spirobranchus giganteus (Pallas, 1766) (Polychaeta, Serpulidae) on southeastern Brazillian coast: new biofouler and free to live without corals? Pan-American Journal of Aquatic Sciences, 7(3): 117-124.

Smith, R.S. 1985. Photorreceptors of Serpulidae polychaetes (Doctoral Thesis). James Cook University, Australia.

Souza, R.C.R. 1989. A Fauna dos Bancos de Areia de Phragmatopoma lapidosa Kinberg, 1867 (Annelida, Polychaeta) da Região de Ubatuba, SP. (Masters Dissertation). Universidade Estadual de Campinas, Brazil.

Straughan, D. 1967. Marine Serpulidae (Annelida: Polychaeta) of Eastern Queensland and New South Wales. Australian Journal of Zoology, 15: 201-261.

Sun, Y.; ten Hove, H.A. \& Qiu, J.W. 2012. Serpulid polychaetes from Hong Kong. Zootaxa, 3424: 1-42. D0I

Sun, Y.; Wong, E.; Keppel, E.; Williamson, J. \& Kupriyanova, E. 2017. A global invader or a complex of regionally distributed species? Clarifying the status of an invasive calcareous tubeworm Hydroides dianthus (Verrill, 1873) using barcoding. Marine Biology, Berlin, 164: 28.

Sun, Y.; Wong, E.; Tovar-Hernández, M.A.; Williamson, J.E. \& Kupriyanova, E.K. 2016. Is Hydroides brachyacantha (Serpulidae: Annelida) a widespread species? Invertebrate Systematics, 30(1): 41-59.

ten Hove, H.A. 1970. Serpulinae (Polychaeta) from the Caribbean: I - the genus Spirobranchus. Studies on the Fauna of Curaçao and other Caribbean Islands, 32: 1-57.

ten Hove, H.A. 1994. Serpulidae (Annelida: Polychaeta) from the Seychelles and Amirante Islands. In: Van der Land, J. 1994. Oceanic Reefs of the Seychelles. Report on a cruise of RT Tyro to the Seychelles in 1992 and 1993. Netherlands Indian Ocean Programme Cruise Reports, 2: 107-116.

ten Hove, H.A. \& Kupriyanova, E.K. 2009. Taxonomy of Serpulidae (Annelida, Polychaeta): The state of affairs. Zootaxa, 2036: 1-126.

Weisbord, N.E. 1962. Late Cenozoic gastropods from northern Venezuela. Bulletins of American Paleontology, 42(193): 1-672.

Wong, E.; Kupriyanova, E.K.; Hutchings, P.; Capa, M.; Radashevsky, V.I. \& ten Hove, H.A. 2014. A graphically illustrated glossary of polychaete terminology: invasive species of Sabellidae, Serpulidae and Spionidae. Memoirs of Museum Victoria, 71: 327-342.

Zibrowius, H. 1970. Contribution à l'etude des Serpulidae (Polychaeta Sedentaria) du Brésil. Boletim do Instituto Oceanográfico, São Paulo, 19: $1-32$. 